\title{
CARACTERÍSTICAS NUTRICIONAIS E ANÁLISE SENSORIAL DE CARNE DE BOVINO PRECOCE E ADULTO
}

ESTEFÂNIA MARIA SOARES PEREIRA

Tese de doutorado apresentada ao Departamento de Nutrição da Faculdade de Saúde Pública da Universidade de São Paulo

Área de concentração: Nutrição

\author{
ORIENTADORA: PROF ${ }^{\mathrm{a}} \mathrm{DR}^{\mathrm{a}}$ \\ MARIA ELIZABETH MACHADO \\ PINTO E SILVA
}

SÃO PAULO 2003 


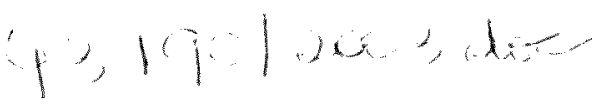

Autorizo, exclusivamente para fins acadêmicos e científicos, a reprodução total ou parcial desta tese, por processos fotocopiadores. Ao usá-lo, cite a fonte.

Assinatura:

Data: 


\section{AGRADECIMENTOS}

- À minha Profa Dra Maria Elizabeth Machado Pinto e Silva pela orientação prestada e incentivo na realização deste trabalho.

- Aos professores membros da banca Dra Elizabeth Torres, Dr. José Cezar Panetta, Dr. Massami Shimokomaki e Dra Carmen Contreras Castilho pelas valiosas sugestões apresentadas ao trabalho.

- Ao Prof. Dr. Marcelo Tavares pelo auxílio às análises estatísticas.

- À professora Heloisa pelo auxilio e sugestões da análise sensorial.

- Ao Núcleo de Produtores de Bovino Precoce do Triângulo Mineiro e Alto Paranaíba pelo incentivo e credibilidade.

- Aos participantes voluntários deste estudo pela colaboração e presteza.

- Aos alunos do curso de Nutrição do Centro Universitário do Triângulo (UNIT) pela colaboração com o trabalho.

- Ao meu marido Paulo e ao meu filho Lorenzo pelo incentivo e reconhecimento.

- A todos que colaboraram direta ou indiretamente para a realização deste estudo. 


\section{RESUMO}

Pereira EMS. Características nutricionais e análise sensorial de carne de bovino precoce e adulto. São Paulo; 2003 [Tese de doutorado - Faculdade de Saúde Pública da USP]

O aumento do interesse aos cuidados com saúde e melhor controle de doenças cardiovasculares e carenciais, vem demonstrando necessidade de estudos de caracterização de carnes com menores teores de gordura, maiores teores de ferro, dentre outros nutrientes, e com boa aceitação sensorial. Objetivos. Avaliar a qualidade nutricional e características sensoriais das carnes de bovino precoce e adulto cruas e grelhadas. Material e métodos. Foram realizadas análises dos teores de umidade, carboidratos, gordura total, gordura saturada, gordura monoinsaturada, gordura poliinsaturada, colesterol, proteinas, valor energético total, ferro e zinco. Para as análises sensoriais de maciez, suculência e sabor, foi utilizada equipe treinada. O método objetivo (texturômetro) foi utilizado para avaliação de textura. Resultados. Quando comparada à carne de bovino adulto, a carne de bovino precoce apresentou redução de $66 \%$ do teor de colesterol e $64 \%$ de gordura total, além de $32 \%$ de redução do valor energético total. Os teores de ferro e zinco da carne de bovino precoce foram superiores, comparando-se com a carne do bovino adulto. $A$ carne de bovino precoce foi escolhida pela equipe de degustadores como a mais macia $(85 \%)$, suculenta $(77,5 \%)$ e saborosa $(85 \%)$, comparada com a carne do bovino adulto. $\mathrm{Na}$ análise de textura, os resultados mostraram-se semelhantes à análise subjetiva, com menor força exercida na carne de bovino precoce. Conclusões. A carne de bovino precoce analisada mostrou-se com características nutricionais importantes para $\circ$ tratamento e prevenção de doenças cardiovasculares e carenciais, além de boa qualidade sensorial.

Descritores: carne, nutrientes, análise sensorial 


\section{SUMMARY}

Pereira EMS. Características nutricionais e análise sensorial da carne de bovino precoce e adulto [Nutritional characteristics and sensory analysis of meat from precocious and adult bovine]. São Paulo (BR); 2003. [PhD Thesis Faculdade de Saúde Pública da Universidade de São Paulo Brazill.

The increasing interest in care with health and better control of cardiovascular and deficiency diseases is showing the necessity of studies of characterization of meats with lower fat contents, higher iron contents, among other nutrients, and with good sensory acceptance. Objectives. To evaluate the nutritional quality and sensory characteristics of uncooked and grilled meat from precocious and adult bovine. Materials and Methods. Analyses of contents of moisture, carbohydrates, total fat, saturated fat, monoinsatured fat, polynsaturated fat, cholesterol, proteins, calories, iron, and zinc were carried out. For sensory analyses of tenderness, juiciness and taste, a team with trained tasters was used. The objective method (texturometer) was used for evaluation of texture. Results. As compared to the meat from mature bovino, the meat from precocious bovine showed $66 \%$ reduction in cholesterol contents and $64 \%$ total fat, besides $32 \%$ reduction of the total caloric value. Iron and zinc contents of meat from precocious bovine were higher compared to the meat from mature bovino. Meat from precocious bovine was chosen by the taste team as the tenderest ( $85 \%)$, juicy $(77.5 \%)$ and tasty $(85 \%)$ as compared to the meat from mature bovino. In the analysis of texture, results showed to be similar to the subjective analysis with lesser strength of shearing applied in the meat from precocious bovine. Conclusions. Meat analyzed from precocious bovine showed important nutritional characteristics for treatment and prevention of cardiovascular and deficiency diseases besides good sensory quality.

Descriptors: Meat, Nutrients, Sensory analysis 


\section{ÍNDICE}

pág.

1. INTRODUÇÃO

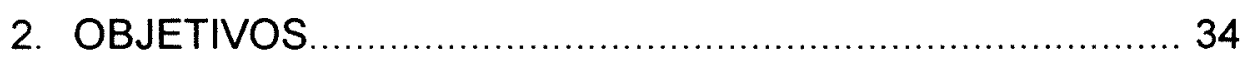

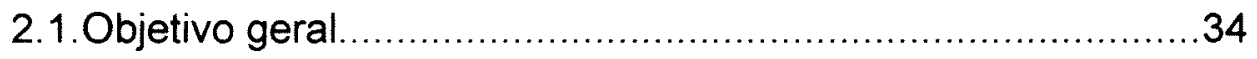

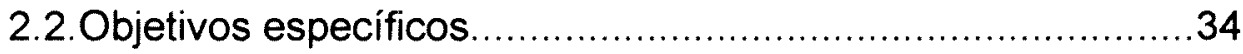

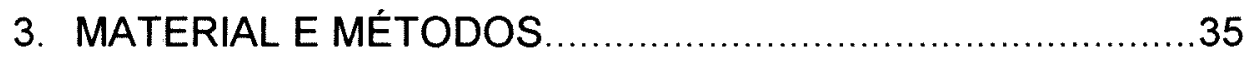

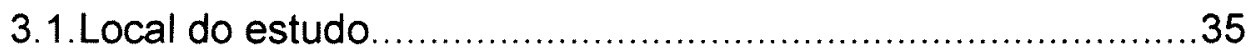

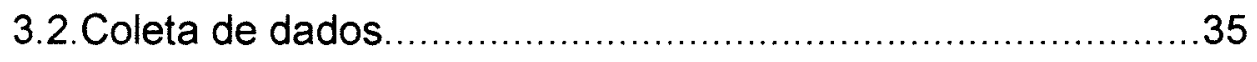

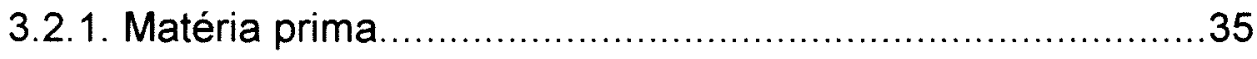

3.2.2. Composição centesimal da carne......................................37

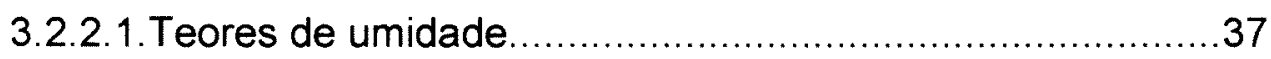

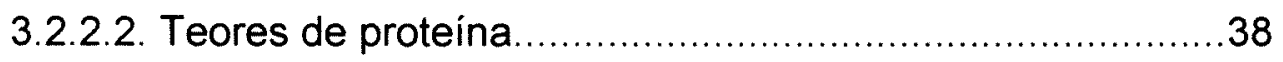

3.2.2.3. Teores de gordura total, ácidos graxos e colesterol..........40

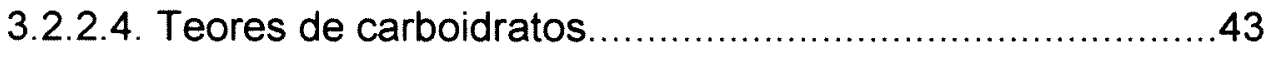

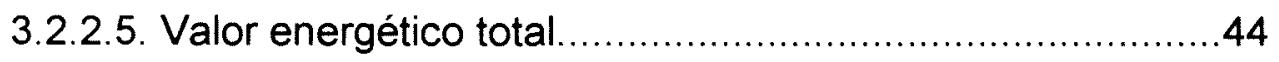

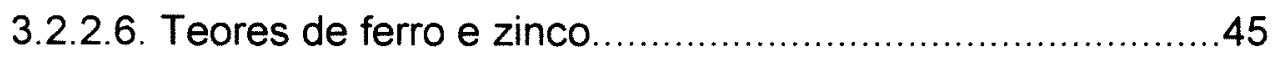

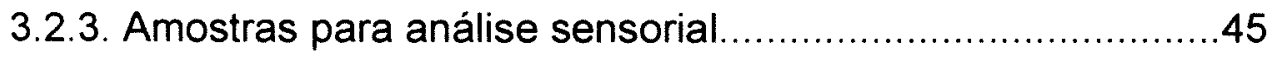

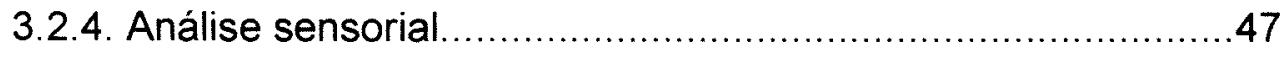

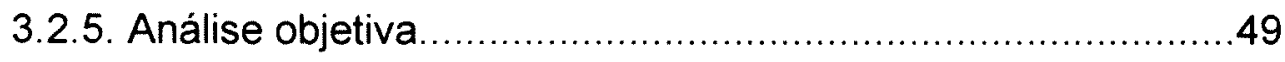

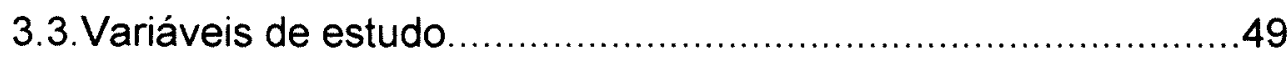

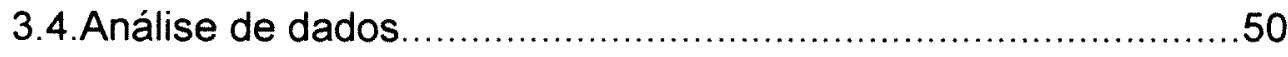

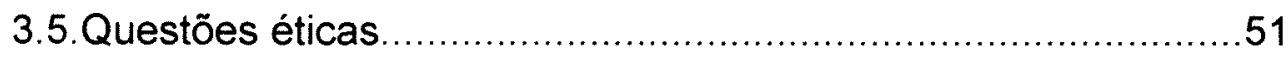

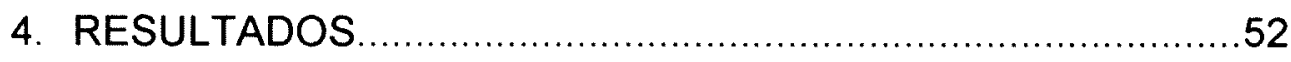

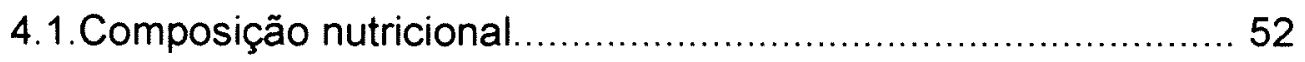




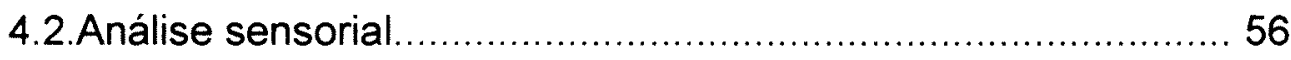

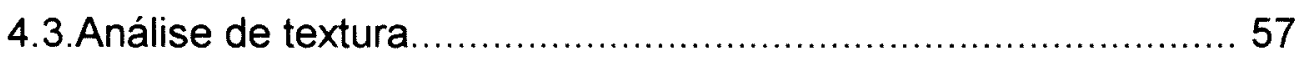

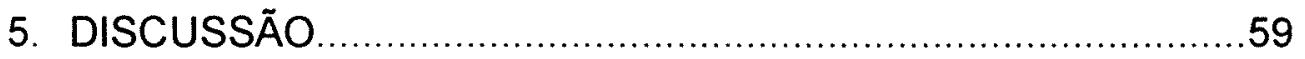

5.1. Composição nutricional................................................59

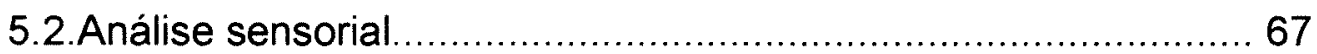

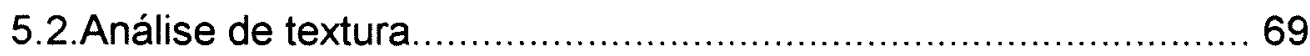

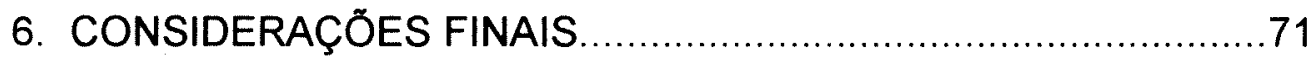

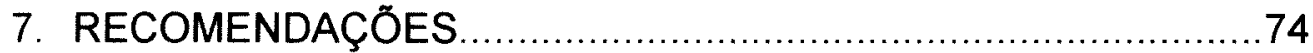

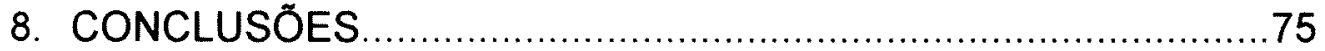

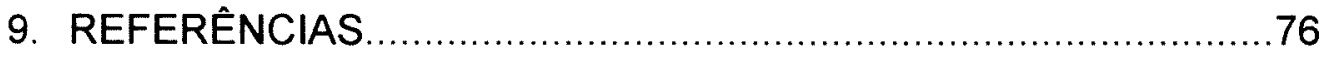

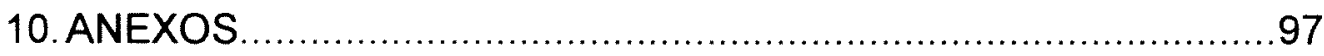

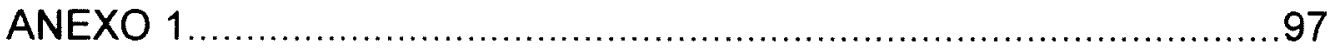

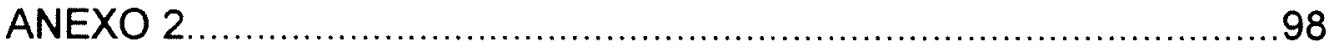

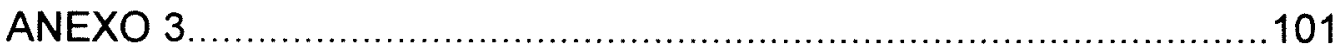

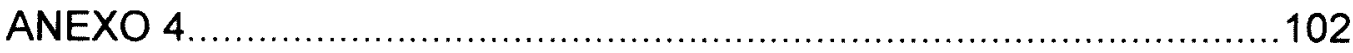




\section{LISTA DE TABELAS}

TABELA 1 - Composição centesimal média e desvio-padrão das carnes de bovino adulto e precoce cruas pág. 52

TABELA 2 - Composição centesimal média e desvio-padrão das carnes de bovino adulto e precoce cozidas. pág. 53 TABELA 3 - Teste t Student de médias das carnes cozidas de bovinos adulto e precoce para as variáveis analisadas pág.54

TABELA 4 - Conteúdo médio e desvio-padrão de ferro e zinco em carnes crua e cozida de bovinos precoce e adulto pág.55

TABELA 5 - Teste t para carne crua e cozida dos bovinos precoces. pág. 55 TABELA 6 - Teste $t$ dos teores de ferro e zinco em carnes crua e cozida de bovinos precoce e adulto pág. 56

TABELA 7 - Freqüências dos avaliadores para maciez, suculência e sabor pág. 56

TABELA 8 - Teste de diferença de proporções para as características avaliadas pelos 40 avaliadores. pág. 57

TABELA 9 - Força $(\mathrm{kgf} / \mathrm{g})$ utilizada no texturômetro, em carne de bovinos precoce e adulto pág. 57

TABELA 10 - Teste $t$ de Student para diferença entre médias, quanto a textura avaliada pelo texturômetro pág. 58 


\section{INTRODUÇÃO}

\subsection{Produção e consumo}

O consumo de carne no ocidente cresceu mais que o dos outros gêneros alimentícios, entre as décadas de 50 e 80, já que representava status, símbolo de poder econômico na sociedade. A partir da década de 80 , houve uma tendência na redução de seu consumo, especialmente da carne bovina, com a perda do seu valor simbólico. Passa-se a acreditar que a carne é dispensável para o equilíbrio dietético. O comportamento e padrão de consumo da carne bovina a, sofre influência do marketing, induzido pelo preconceito da dificuldade digestiva, problemas cardiovasculares e a baixa qualidade de vida (BLEIL 1997; FABRINI FILHO \& SILVA 1997). De acordo com estudo realizado pelo Centro Tecnológico da Carne (CTC) e Instituto de Tecnologia de Alimentos (ITAL), 55\% dos entrevistados consideram que o consumo de carne bovina pode causar algum mal à saúde, $23 \%$ não sabem o que pode causar, $19 \%$ referem que influencia os níveis de colesterol sangüíneo e $82 \%$ são receosos pela presença de antibióticos e resíduos hormonais na carne (SCVCF 1999).

Há um aumento no número de jovens adultos, especialmente mulheres, adotando dietas vegetarianas justificando a saúde, questões ambientais e animais da seguinte forma: "a carne bovina é agente causador de doenças cardiovasculares e câncer; é responsável pela destruição de florestas tropicais e 
equatoriais (retirada das árvores dando lugar aos pastos) e aquecimento da temperatura mundial; provoca escassez de água (lixo orgânico depositando-se em rios) e é causadora de fome no mundo (colheitas de grãos usadas como alimentação animal e, não humana) (JANELLE \& BARR 1995).

O mercado internacional da carne bovina foi abalado nos últimos anos em função do aparecimento da Encefalopatia Espongiforme Bovina (EEB), a síndrome da vaca louca, com sintomas neurológicos irreversíveis ao homem. O Brasil não foi afetado por esta patologia, porém, medidas sanitárias tornaram-se urgentes, com a proibição, de importação, comercialização e exposição de produtos advindos dos mercados afetados (GERMANO 2001). Esta questão sanitária da carne, exposta de maneira duvidosa ao mundo, enfatiza a necessidade de prevenir a adulteração dos produtos que podem causar doenças ao consumidor. Para isto está sendo sugerida a implementação de análise de perigos e pontos críticos de controle (HACCP) nas indústrias de carnes (DREESEN 1998).

No que diz respeito à industrialização da carne no Brasil, em 1996, muitas empresas tiveram prejuízo na produção, devido ao aumento de preços do milho e soja, facilidade de importação de bovinos da Argentina e Uruguai e defasagem de preços em função do Plano Real, além dos efeitos da globalização da economia (TERRA 1998). A alta carga tributária no Brasil provocou a saída de número representativo de empresas do setor frigorifico e incentivou a evasão fiscal como alternativa de sobrevivência, sendo um dos principais motivos da falta de 
organização do setor, além da falta de uniformidade dos impostos nos vários estados brasileiros, prejudicando também as exportações (NEVES et al. 2001).

O Brasil, Estados Unidos, Austrália, Irlanda, Japão, Nova Zelândia são considerados os grandes exportadores de carne bovina, tendo o Brasil aumentado sua participação de 4\%, em 1996, para 9\%, em 1999. Várias são características que determinam a posição do Brasil, incluindo extensão territorial, diversidade climática, facilidade de adaptação da raça zebuína aos trópicos. Os maiores mercados importadores do Brasil são Estados Unidos, Japão, França, Itália e Alemanha (NEVES et al. 2001).

O quadro 1 mostra a posição dos principais paises produtores de carne bovina, podendo-se observar, estabilidade pelo aumento da competitividade nos últimos anos:

Quadro 1: Produção mundial de carne bovina em mil toneladas de equivalentecarcaça

\begin{tabular}{|llllll|}
\hline Ano & $\begin{array}{l}\text { Estados } \\
\text { Unidos }\end{array}$ & Brasil & China & Argentina & Austrália \\
\hline 1997 & 11.714 & 6.402 & 4.409 & 2.975 & 1.942 \\
1998 & 11.804 & 6.504 & 4.799 & 2.600 & 1.989 \\
1999 & 12.124 & 6.562 & 5.054 & 2.840 & 1.956 \\
2000 & 12.298 & 6.697 & 5.328 & 2.880 & 1.988 \\
$2001^{*}$ & 11.955 & 6.930 & 5.600 & 2.860 & 2.000 \\
$2002^{\star *}$ & 11.626 & 7.322 & 5.880 & 2.900 & 2.040 \\
\hline
\end{tabular}

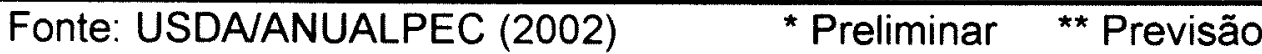


Em 1970, o consumo interno anual per capita de frango era de $2,3 \mathrm{~kg}$, de bovinos $12,1 \mathrm{~kg}$, este último atingindo $20,6 \mathrm{~kg}$ em 1978 e decaindo progressivamente para $11,8 \mathrm{~kg}$ em 1987 . Os dados de consumo per capita para carne bovina, de frango e suína, nos últimos anos, são aqueles apresentados no quadro 2, mostrando destaque para a estabilidade relativa ao consumo de carne bovina e aumento considerável para a carne de frango (ANUALPEC 2002):

Quadro 2: Consumo per capita $(\mathrm{kg})$ anual de carnes no Brasil

\begin{tabular}{|llllllllll|}
\hline Carne & 1994 & 1995 & 1996 & 1997 & 1998 & 1999 & 2000 & 2001 & $2002^{*}$ \\
\hline Boi & 38,0 & 42,6 & 42,4 & 38,9 & 38,1 & 36,4 & 36,5 & 35,8 & 37,6 \\
Frango & 19,5 & 23,4 & 22,2 & 23,8 & 26,0 & 28,6 & 29,9 & 30,8 & 32,3 \\
Porco & 10,4 & 11,2 & 10,8 & 10,3 & 10,0 & 11,2 & 12,3 & 11,5 & 11,0 \\
\hline
\end{tabular}

Fonte: USDAVANUALPEC (2002) " Projeção

Os dados preliminares (2001) de consumo per capita de carne bovina mostram a Argentina $(73,0 \mathrm{~kg})$, o Uruguai $(67,3 \mathrm{~kg})$ e os Estados Unidos $(44,4 \mathrm{~kg})$, como os principais consumidores do mundo (ANUALPEC 2002).

Os paises que mais consumiram carne de frango, em 2001, foram Estados Unidos (11.164 mil toneladas), seguido da China (5.629 mil toneladas) e do Brasil (5.154 mil toneladas) (ANUALPEC 2002).

Comparando-se a média dos preços da arroba de boi no mercado mundial de gado, entre os anos de 1997 e 2001, encontramos os Estados Unidos 
com US $\$ 51,01$; Argentina, com US $\$ 22,76$; Uruguai, US $\$ 18,70$; Brasil, US $\$ 18,34$; seguido do Paraguai com US $\$ 15,53$ (ANUALPEC 2002).

Apesar das estimativas do aumento do consumo per capita de carne bovina no Brasil e do preço de mercado da carne bovina ser considerado um dos mais baixos no mercado mundial, existem distorções regionais, já que 9 milhões de gaúchos consomem $70 \mathrm{~kg} / \mathrm{ano}$, enquanto 35 milhões de nordestinos consomem apenas $5 \mathrm{~kg} / \mathrm{ano}$ (SCVCF 1999).

No Brasil, falta tratamento adequado de abate de bovinos, respeito ao tempo do rigor mortis, conservação, combate à febre aftosa, além de educação nutricional. Aliado a isto, as carnes do quarto dianteiro do bovino não são preparadas adequadamente em relação aos métodos de cocção e os cortes são feitos, muitas vezes, no sentido das fibras, o que compromete a suculência e maciez. Isto reduz o número de consumidores da carne bovina, especialmente aqueles de baixa renda, que acabam aumentando o consumo de frango. Porém, o incentivo ao consumo da carne de frango justificado pelo preço, não leva em consideração a perda do peso do produto em função da carcaça, em média, $50 \%$. Isto torna o valor do peso líquido da carne de frango, próximo ao da carne bovina, especialmente quando é analisado o preço da considerada "carne de segunda" localizada na parte anterior do corpo do animal. Há indícios, portanto, que o fator preço não é o principal na determinação do consumo aumentado da carne de frango, pois a carne localizada no quarto dianteiro - geralmente comercializada a um menor preço no Brasil - poderia ter incentivado o consumo de carne bovina 
(SILVA \& FABRINI FILHO 1998). Por isso, aliado aos fatores descritos, para o aumento do consumo de carne bovina no Brasil, é necessário o marketing em todos os elos da cadeia de produção e comercialização (LAZZARINI NETO 1995).

A pecuária de corte brasileira tem dificuldades relacionadas ao desempenho econômico e produtivo dos sistemas de produção, apresentando limitações de desempenho do animal, de gerenciamento, de mercado e mão de obra (CEZAR \& FILHO 1996). As negociações internacionais ainda são fracas e a desvantagem competitiva é grande, apesar dos dados de exportação (NEVES et al. 2001).

O rastreamento do animal é cada vez mais uma exigência dos consumidores europeus e necessária para se estabelecer critérios de controle e qualidade da carne, desde o processo de cria, nas fazendas, até à mesa do consumidor. Desta forma, facilita-se o processo de reconhecimento da carne pelo consumidor, através de selos fixados nos produtos. Estes produtos têm sido vendidos em alguns supermercados no Brasil, devidamente supervisionados, mostrando aos potenciais consumidores, segurança e garantia (FELÍCIO 1999).

A diversidade na produção para atender diferentes mercados, através de um mesmo produto, é fator importante para a competitividade (STRADIOTTI 2002). De acordo com ALMEIDA (1998), tendências atuais do mercado de carnes indicam necessidade de agregação de praticidade; menor índice de gordura e, consequentemente de colesterol; além da certificação de qualidade e origem. $\mathrm{O}$ 
conceito de qualidade da carne é muito variado. Além de hábitos regionais que determinam as preferências, a renda, a cultura e o nível do estágio de desenvolvimento tecnológico da sociedade são fatores a serem avaliados. A estratificação do consumo de carne é influenciada não só por características organolépticas mas também pelo aspecto nutricional. Os teores de gordura de cobertura e entremeada na carne (em uma proporção de 3 a $4 \%$ do músculo) definem características de maciez, sabor, suculência. Porém, existem consumidores preocupados com os aspectos negativos para a saúde, relacionados ao consumo de carne com altos teores de gordura.

Pesquisa realizada nos EUA, destacando fatores mais importantes na escolha da carne, revelaram as seguintes preferências entre os consumidores: $88 \%$ valorizavam o sabor em primeiro lugar, seguido pelo valor nutricional $(78 \%)$; a segurança ocupou o terceiro lugar e o preço, a quarta colocação. No Brasil, pesquisa realizada pelo ITAL revelou as características que mais impressionam os consumidores no ato da compra: para $52 \%$, a aparência da carne; $28 \%$, preço, seguidos dos aspectos relacionados com a presença de gordura e a higiene do estabelecimento (SCVCF 1999).

Ainda no Brasil, $60 \%$ dos consumidores de carne bovina é formada por individuos de faixas de rendas inferiores e que dão maior importância ao preço da carne quando comparado à qualidade. Além disso, eles rejeitam a carne se a coloração estiver escura e com excesso de gordura. Por volta de $30 \%$ dos consumidores valorizam a carne magra, considerando maciez e suculência como 
características secundárias. Já o segmento composto por indivíduos de alto poder aquisitivo - em média, $10 \%$ da população - selecionam a maciez e suculência como características essenciais da carne (LAZZARINI NETO 1995).

Nota-se, especialmente nos níveis de renda mais elevados, o aumento do consumo de produtos processados no lugar dos in natura, ou seja, na forma de cortes comuns com valor agregado como congelados, empanados, empacotados, defumados inteiros e cortes especiais (GRUNERT 1997; SABA \& Di NATALE 1998; SCVCF 1999).

De acordo com KATZ (1999), houve um aumento da ingestão de alimentos prontos e semi-prontos, porém, muitos deles, apesar de terem altos valores calóricos, têm baixos teores de nutrientes essenciais que devem ser ingeridos diariamente.

Apesar da tendência do mercado atual, o rebanho brasileiro é ainda, pouco precoce e tem desempenho produtivo e reprodutivo baixo, o que faz com que o desfrute do rebanho ainda seja baixo (CEZAR \& FILHO 1996; STRADIOTTI 2002). O animal, nesta condição é abatido, geralmente com 2 anos ou menos, sendo a metade do tempo de abatimento do bovino tratado pelo método tradicional. A carne é mais tenra, mais palatável, considerada de alta qualidade sob $\circ$ ponto de vista nutricional e comercial, o que elimina desperdícios. Considerando aspectos econômicos, o abatimento precoce libera pastagem para ser usada para novos animais; economiza alimentação do rebanho; não onera 
custos no sistema de criação; aumenta a competitividade dos frigoríficos e o giro de capital é mais rápido. Para o estado, a arrecadação do ICMS se dá em dois anos e não em quatro anos originalmente com rebanho bovino tradicional. A sonegação de impostos e clandestinidade diminuem, já que os produtores são melhor remunerados através dos incentivos fiscais e econômicos concedidos e do aumento da produtividade (ALMEIDA 1998; PIRES 1998; COSTA 2000).

A carne bovina brasileira não tem uma demanda de consumo bem definida, relacionada à qualidade. O baixo poder aquisitivo do mercado interno, as flutuações de preços e falta de diferenciação de preço por qualidade da carne dificultam a viabilidade do sistema de produção (CEZAR \& FILHO 1996).

No Brasil, os principais estados produtores e consumidores de carne bovina (Mato Grosso, São Paulo, Goiás e Minas Gerais) têm trabalhado com produção de bovinos precoces, que constitui um dos índices de produtividade. $O$ Mato Grosso foi o pioneiro nesta criação e também o investidor inicial da chamada "cadeia mercadológica", que integra cadeia produtiva de carnes, desde o produtor local até o consumidor regional, com ênfase na produção de bovino precoce (ALMEIDA 1998). 
O quadro abaixo mostra a evolução no abate de bovinos precoces no Brasil:

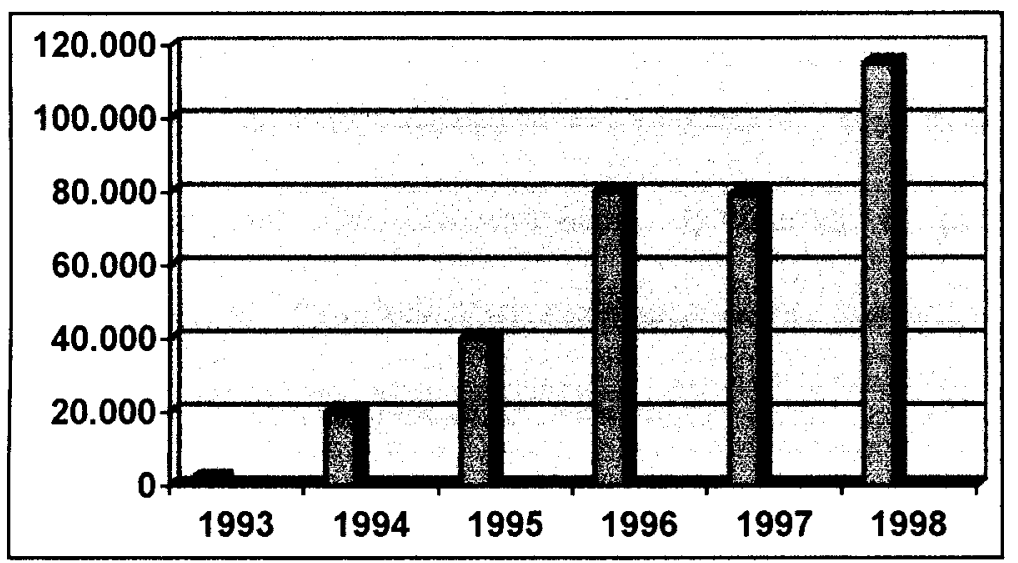

Distribuição do número de abates de bovino precoce/ano ( ALMEIDA 1998)

\subsection{Composição química e importância para a saúde}

Uma alimentação balanceada é elemento decisivo para se obter bem estar e saúde. A ingestão inadequada de micronutrientes continua sendo um grande problema que afeta mais de $1 / 3$ de pessoas em todo o mundo, provocando danos físicos e intelectuais, comprometendo as atividades diárias e sobrevivência, principalmente de mulheres e crianças, inclusive em paises desenvolvidos (SOLEH \& AHMED 1998; KATZ 1999).

A carne bovina é rica em nutrientes essenciais à manutenção da saúde. Além de proteínas de alto valor biológico e ácidos graxos, ela é a principal fonte de vitaminas do complexo B, dos minerais ferro e zinco (WHO 1985; WATTS et al. 
1988; PEARSON \& DUTSON 1990; BELLIZZI et al. 1994; KEENAN \& MORRIS 1995; SMIT et al. 1999).

A carne bovina é rica em vitamina B1 (Tiamina), que desempenha papel importante no metabolismo de carboidratos, gorduras e proteínas e cuja deficiência leva à anorexia, insuficiência cardiaca e no sistema gastrointestinal (SANT'ANA et al. 1998; UZCÁTEGUI et al. 1999).

A vitamina B12 (Cianocobalamina) é encontrada cerca de nove vezes mais na carne bovina quando comparada à carne de frango e está freqüentemente em quantidades marginais nos indivíduos consumidores de dietas vegetarianas exclusivas, que não recebem suplementação (KEENAN \& MORRIS 1995).

A vitamina B2 (riboflavina), essencial para a formação de células vermelhas do sangue, embora esteja distribuída mais amplamente nos alimentos, tem a carne bovina como um dos seus principais fornecedores, junto com o leite e derivados. A vitamina B6 (Piridoxina) tem como principal fonte a carne bovina, seguida dos cereais (WATTS et al. 1988; KEENAN \& MORRIS 1995).

De acordo com estudo realizado por JANELLE \& BARR (1995), com mulheres de 20 a 40 anos, moradoras de área metropolitana do oeste do Canadá, - vegetarianismo esteve associado com baixo consumo de alimentos calóricos e com anorexia nervosa, indicando risco de deficiências nutricionais. Ainda, a média 
de ingestão de zinco e vitamina B12 por vegetarianas era menor que $70 \%$ da RDA (Recomended Dietary Allowances), para ambos os nutrientes.

CADE et al. (1998), analisando dados preliminares de um estudo de coorte, realizado com mulheres inglesas, entre 35 e 69 anos (UK Women's Cohort Study), compararam ingestão de nutrientes entre mulheres que consumiam com outras que não consumiam carne. Aquelas que não consumiam tinham ingestão significativamente menor de energia, proteína, zinco e gordura. Porém, surpreendentemente, não houve diferença significativa entre a ingestão de ferro pelos dois grupos, justificado pela utilização de cereais fortificados com ferro, pelo grupo que não ingeria carne.

Estudo sobre consumo alimentar, realizado por GALEAZZI et al. (1997), em 5 cidades do sudeste brasileiro, mostrou que a carne bovina estava entre os 10 alimentos com maior contribuição de proteína e energia na dieta das famílias analisadas, para todas as cidades, sendo considerado alimento muito apreciado pela população estudada. Os resultados do estudo destes autores mostram adequação do consumo de proteínas de 89 a $216 \%$, mostrando excesso de ingestão deste nutriente por alguns grupos e deficiência de sua ingestão por outros. O excesso acontecia especialmente quando a faixa de renda aumentava. Já a deficiência de ingestão acontecia nas faixas de renda menores, mostrando necessidade de adequação para este grupo e chamando a atenção para a necessidade de levantamento de dados em outras regiões do país menos favorecidas economicamente. 
A proteína da carne é constituída de 20 aminoácidos essenciais para formação e renovação tecidual (SHAW et al. 1995). De acordo com a Food and Agriculture Organization (FAO 1985) o ser humano deve ter suprimento diário de 90 gramas de proteína, sendo $50 \%$ de origem animal. O tipo de proteína da dieta é, também, um bom marcador de diferenças de dados de prevalência de deficiência de ferro em diferentes paises (REDDY et al. 1996).

De acordo com KATZ (1999), houve um aumento da ingestão de alimentos prontos e semi-prontos, porém, muitos deles, apesar de terem altos valores calóricos, têm baixos teores de nutrientes essenciais que devem ser ingeridos diariamente.

Alguns aminoácidos, como cisteína, obtidos a partir da digestão de proteina animal e ácidos orgânicos produzidos pela fermentação (cítrico, láctico, butírico, acético e fórmico) têm a capacidade de aumentar a absorção de zinco. Isto ocorre, provavelmente, por formarem ligantes solúveis com o zinco ou por evitarem a formação de um complexo insolúvel do zinco com o fitato (GIBSON et al. 1998; GIBSON \& FERGUSON 1998).

O zinco tem como principal fonte, especialmente em países ocidentais, a carne bovina, em proporção de $50 \%$ da necessidade dietética, seguida da carne de suínos e derivados do leite. A quantidade deste mineral na carne bovina supera a da carne de frango em quatro vezes. Amendoins também são fontes de zinco, apesar de possuirrem menores concentrações. Este mineral é especialmente 
importante para idosos, já que muitos têm baixa ingestão dos alimentos fontes (WATTS et al. 1988; KEENAN \& MORRIS 1995; BLACK 1998; GIBSON et al. 1998).

A maior parte dos estudos realizados com zinco têm sido conduzidos durante a infância. Estudo de KIRKSEY et al. (1994) mostrou que baixos estoques de zinco da mãe têm sido associados com menor atenção durante o período neonatal. GOLUB et al. (1996) encontraram pior funcionamento motor aos 6 meses de idade, quando estes estoques eram precários na mãe.

Evidências recentes sugerem que a deficiência do mineral traço zinco pode estar associada ao déficit do crescimento, função imune, desenvolvimento cognitivo e motor, comportamento e rendimento escolar, já que são ocorrências freqüentes em crianças com esta deficiência. Está envolvido no processo de crescimento celular, especialmente na produção de enzimas necessárias para a sintese de DNA (ácido desoxiribonucléico) e RNA (ácido ribonucléico). Letargia e apatia são sintomas comuns na deficiência de zinco (GOLUB et al. 1996; BLACK 1998; GIBSON et al. 1998).

Altas concentrações de cálcio potencializam o efeito inibitório do fitato na absorção de zinco em humanos, através da formação de complexo cálcio-zincofitato no intestino. Em geral, os alimentos não industrializados têm quantidades pequenas de cálcio para potencializar o efeito negativo do fitato sobre a absorção 
de cálcio, com exceção daqueles presentes nas dietas lactoovovegetarianas (GIBSON \& FERGUSON 1998).

Existem outros componentes da dieta que podem inibir a absorção de zinco. Nos países menos industrializados, as dietas ricas em fibras podem influenciar esta absorção. Os efeitos da fibra e fitato, porém, são confundidos, pois, geralmente, estão presentes juntos nos mesmos alimentos. Suas influências independentes são, portanto, difíceis de serem estabelecidas (GIBSON 1994). O tipo de fibra envolvido é importante e, parece que as fibras do tipo insolúvel potencializam o efeito adverso do fitato na absorção de zinco. Apesar de existirem vários métodos para análise de fibras nos alimentos, alguns deles são limitados (GIBSON 1998).

SHAW et al. (1995) estudaram jovens vegetarianos chineses budistas e jovens não vegetarianos, em Taiwan, com idades inferiores a 30 anos. Encontraram, para vegetarianos de ambos os sexos, valores de ferritina plasmática $50 \%$ menores que os valores dos não vegetarianos, apesar da ingestão de ferro de ambos ter sido maior ou próxima à quantidade recomendada. Para as mulheres vegetarianas, mesmo quando tinham ingestão calórica adequada, a hemoglobina tinha valores significativamente menores que as não vegetarianas, fato indicativo de que a biodisponibilidade do ferro foi a maior determinante para a inadequação da dieta vegetariana. 
Os budistas seguem dieta vegetariana, com larga utilização de soja e, consequentemente, com baixa porcentagem de absorção de ferro. Apesar disso, são escassos os estudos sobre o impacto das possiveis deficiências nutricionais (SHAW et al. 1995).

A absorção de ferro é altamente variável e depende não só dos niveis deste mineral no organismo, mas também de outros fatores da dieta que aumentam ou inibem sua absorção. A baixa biodisponibilidade, portanto, é uma questão de grande importância, especialmente em países em desenvolvimento, onde dietas podem conter altos níveis de inibidores de absorção (YIP 1994; TSENG et al. 1997; DEMAYER et al. 1989; SANTIAGO et al. 2001).

TSENG et al. (1997) avaliaram fatores interferentes na absorção de ferro e observaram baixa adequação de ferro da dieta. Nas zonas rurais, especialmente, encontraram baixa biodisponibilidade, o que aumenta o risco de conseqüências em função das deficiências nutricionais, para vários grupos populacionais.

Em estudo multicêntrico sobre consumo alimentar, realizado em Goiânia, Campinas, Rio de Janeiro, Ouro Preto e Curitiba foram encontradas porcentagens altas de indivíduos com consumo inadequado de ferro. Em média, $37 \%$ dos jovens do Rio de Janeiro, com idades entre 15 e 25 anos, de ambos os sexos, apresentaram ingestão inadequada deste mineral, dado semelhante ao encontrado em Curitiba. Em Goiânia, a inadequação para a mesma faixa etária, 
nos dois sexos, foi de 60\%. Campinas (média de 15\%) e Ouro Preto (média de 5\%) tiveram índices menores de inadequação de ferro, considerando mesma faixa etária e ambos os sexos (GALEAZZI et al.1997).

A deficiência de ferro continua sendo uma das mais comuns carências nutricionais no mundo, tanto em paises desenvolvidos quanto em paises em desenvolvimento. Estima-se que $30 \%$ da população mundial seja anêmica. No Brasil, 1/3 das gestantes são afetadas pela deficiência de ferro, sendo de ocorrência comum em crianças até 24 meses (SANTIAGO et al. 2001; MINISTÉRIO DA SAÚDE 2002). De acordo com a Organização Mundial de Saúde (OMS), $50 \%$ das crianças que vivem em paises em desenvolvimento têm anemia ferropriva (FUNDO DAS NAÇÕES UNIDAS PARA A INFÂNCIA 1995). Os baixos níveis sangüíneos de ferro, especificamente, têm sido associados com a diminuição da função imune, da resistência a infecções e da capacidade de trabalho, além do aumento do risco de nascimento pré termo e de baixo peso (TSENG et al. 1997).

Estudo conduzido por SILVA (2000) encontrou número significativo de crianças menores de 36 meses, anêmicas, matriculadas em creches de Porto Alegre. Esta relação aumenta quanto menor o nivel sócio econômico.

As reservas de ferro são geralmente menos adequadas em mulheres em período fértil quando comparadas com os homens, devido às perdas sangüíneas. A ingestão de alimentos fontes de calorias também tem sido menor em mulheres, 
levando à conseqüente redução da ingestão de ferro. Portanto, o consumo de carne contribui significativamente com a ingestão total e estoque adequado deste mineral (KEENAN \& MORRIS 1995; SHAW et al. 1995).

A determinação da ingestão alimentar total e de nutrientes específicos é uma estratégia importante para adequar a dieta, de acordo com as necessidades individuais (TSENG et al. 1997).

Vários estudos populacionais têm encontrado relação entre alto consumo de carne e várias doenças do coração (SACKS et al. 1981; SNOWDON et al. 1984; SLATTERY et al. 1991; NICKLAS et al. 1995). Já outros estudos clínicos têm mostrado que a carne magra não afeta os níveis de colesterol total quando adicionada à dieta (O'BRIEN \& REISER 1980; FLYNN et al. 1982; WATTS et al. 1988; O'DEA et al. 1990).

O' BRIEN \& REISER (1980) verificaram a resposta lipídica plasmática para carne bovina, frango, peixe e ovos, em indivíduos de 31 a 61 anos, com concentração plasmática de colesterol menor que $240 \mathrm{mg} / \mathrm{dl}$ e não encontraram diferenças significativas das respostas aos diferentes tipos de carnes.

Em relação ao consumo de gorduras, as recomendações visam a redução da ingestão de gordura total para $30 \%$ do total de energia, sendo $10 \%$ de ácidos graxos saturados do total de energia e, colesterol da dieta, para menos que $300 \mathrm{mg}$ (NICKLAS et al. 1995; HAILE et al. 1997). 
É grande $O$ interesse em estudos sobre os diferentes tipos de ácidos graxos e seus efeitos no organismo humano. Apesar de muitas controvérsias, uma dieta com altos teores de gordura tem sido considerada a maior causa de doenças cardiovasculares (GOTTO 1990; LARYSSE \& GARCÍA-CASAL 1997; GUILLAUME et al. 2000).

Modificações na proporção de gordura saturada e colesterol ingeridos através da dieta têm sido utilizadas como estratégia na redução plasmática de lipoproteínas de baixa densidade e colesterol total (HOEG 1997; NICKLAS et al. 1989; WILLETT 1998; NIH 2001).

De acordo com CLEEMAN \& LENFANT (1998), altas concentrações plasmáticas de colesterol total e LDL - colesterol e baixa concentração de HDL colesterol são associados com risco de doenças cardiovasculares.

KASIM - KARAKAS et al. (2000) estudando 64 mulheres saudáveis, com idade média de 61 anos (DP = 11 anos), em período pós-menopausa, recebendo dieta com baixos teores de lipídeos (15\%), verificaram redução significativa de peso e HDL - colesterol depois de 4 a 8 meses. Os resultados obtidos sugeriram que, as recomendações de ingestão de lipídeos pela dieta devem ser individualizadas. Ainda, apesar da restrição de lipídeos da dieta ser desejável para promoção da perda de peso ou prevenção de alguns canceres relacionados à dieta, pode não ser necessária para a prevenção de doenças cardiovasculares. 
Muitos estudos têm mostrado que a substituição de carne bovina por frango ou peixe na dieta não apresenta vantagem em termos de redução de níveis de lipídeos sangüíneos (O'BRIEN \& REISER 1980; SCOTT et al. 1994; KEENAN \& MORRIS 1995; KRIS-ETHERLON \& YU 1997).

De acordo com KESTIN et al. (1989), MORGAN et al. (1993) e KEENAN \& MORRIS (1995), dietas com o objetivo de reduzir a ingestão de gordura saturada poderiam incluir carne bovina com baixos teores de gordura.

Em estudo feito por KESTIN et al. (1989), o uso de carne bovina com baixos teores de gordura para indivíduos em dieta hipocolesterolêmica produziu um decréscimo médio de $5 \%$ nos níveis de colesterol sangüíneo, a curto prazo.

Alguns importantes estudos anteriores já haviam encontrado resultados similares no efeito da redução do risco de doenças cardiovasculares (KEYS et al. 1957; HEGESTED 1965; DAYTON et al. 1968; KATO et al. 1973; TURPEINEN et al. 1979).

O'DEA et al. (1990) avaliaram a contribuição das carnes bovina com baixo e alto teor de gordura na elevação de colesterol total, em 10 indivíduos saudáveis. Neste estudo, após uma semana de observação, o nível de colesterol total diminuiu significativamente com dieta reduzida em gordura, porém houve aumento dos níveis de colesterol sangüíneo quando a dieta com carne com elevado teor de gordura era retomada. 
Outro estudo, conduzido por O'BRIEN \& RAISER (1980), avaliou as recomendações, de várias organizações de saúde, para substituir frango e peixe por carne bovina, para reduzir a ingestão de colesterol para menos de $300 \mathrm{mg} / \mathrm{dia}$. Os resultados mostraram que os niveis lipídicos não foram afetados pela ingestão de carne bovina ou de porco, frango ou peixe. Porém, $50 \%$ dos participantes do estudo tiveram niveis maiores de colesterol, após o consumo de 3 ovos, por 12 semanas. Estes resultados indicaram que, dietas com baixo teor de gordura e contendo carne bovina ou frango pode reduzir os níveis lipídicos do sangue. A substituição frango por carne bovina não modifica níveis lipídicos.

KESTIN et al. (1989) compararam o poder hipocolesterolêmico e de redução de pressão arterial de uma dieta com alto conteúdo de gordura, outra ovolactovegetariana e, a terceira, teve $60 \%$ da proteína da dieta ovolactovegetariana substituída por carne com menos de $7 \%$ de gordura. A dieta ovolactovegetariana apresentou melhores resultados em relação à redução de colesterol sérico e pressão arterial, tendo a dieta rica em gordura, o pior resultado. Aquela dieta com carne magra apresentou resultados intermediários, porém devese considerar a importância dos nutrientes proteína, ferro e zinco que não estariam adequados em relação às recomendações nutricionais, utilizando-se a dieta ovolactovegetariana. A qualidade da dieta não deve ser analisada de maneira isolada. O controle de todos os nutrientes fontes é a garantia da qualidade da dieta fornecida. 
KEENAN \& MORRIS (1995) consideraram desnecessária a exclusão de carnes de qualquer animal da alimentação, com 0 intuito de reduzir níveis lipídicos. Sugeriu o controle de porções, seleção de cortes mais magros e redução da ingestão excessiva de alimentos com altas concentrações de gordura.

Algumas pesquisas têm sugerido que o colesterol elevado das carnes bovinas é atribuido à carne com mais de $10 \%$ de gordura e que a carne magra pode facilmente contribuir na redução do colesterol da dieta (O'DEA et al. 1990; MORGAN et al. 1993; DENKE 1994).

WATTS et al. (1988) testaram a resposta plasmática de lipídeos e lipoproteínas, para três dietas normocalóricas, em hipercolesterolêmicos. A dieta referência $(A)$ tinha $42 \%$ de energia proveniente de gordura; a outra era de $35 \%$ de energia proveniente de gordura (B) e a terceira dieta tinha $27 \%$ de energia proveniente de gordura, além de suplemento de fibras (C). A quantidade de carne era a mesma para as três, sendo $180 \mathrm{~g} / \mathrm{dia}$, porém com carne contendo alto teor de gordura, valores intermediários de gordura e carne com menores teores de gordura, respectivamente. Durante o consumo da dieta B, a concentração plasmática de colesterol total caiu $8,6 \%$ e o LDL - colesterol, $11 \%$. Durante o consumo da dieta C, a concentração plasmática de colesterol total caiu $18,5 \%$ e o LDL - colesterol, $23,8 \%$, indicando redução do risco de doenças cardiovasculares. Os triglicerídeos e HDL - colesterol não se modificaram significativamente durante o estudo. 
Os resultados do estudo de coorte de 14 anos, de HU et al. (1999), com 80082 mulheres, nas idades entre 34 e 59 anos, mostraram que uma alta ingestão dietética de ácidos graxos saturados foi associada com um aumento do risco de doenças cardiovasculares, porém, as ingestões média e baixa não foram associadas a doenças cardiovasculares. A ingestão exagerada de carne bovina e produtos lácteos com alto teor de gordura, principais fontes de ácidos graxos saturados na dieta, também foi associada a risco significativamente maior. Em contraste, ingestão de frango, peixe e produtos lácteos com baixo teor de gordura foi associada com baixo risco. Encontraram ainda, uma forte relação inversa entre a proporção de gordura poliinsaturada:saturada e o risco de doenças cardiovasculares.

FORNÉS et al. (2000) e FORNÉS et al. (2002) realizaram estudo com 1045 adultos, de ambos os sexos, no município de Cotia, São Paulo, aplicando como método, um inquérito com informações sócio demográficas, clínicas, dietéticas, determinação de níveis séricos de colesterol e suas frações, além de levantamento de dados antropométricos e estilo de vida. O consumo de carnes, leite e derivados correlacionou-se positivamente com LDL - colesterol. Aqueles indivíduos que apresentavam alto consumo de alimentos considerados como de risco para doenças cardiovasculares (escore I) tinham niveis de colesterol e LDL colesterol mais altos que aqueles pertencentes aos quintis inferiores do escore I. Porém, de maneira inversa, os indivíduos que consumiam hortaliças, frutas, leguminosas ou cereais e derivados (escore II) tinham média maior de colesterol total no primeiro quintil, comparando-se com os demais. Além disso, estes 
apresentaram uma redução nos níveis de $L D L$ - colesterol de $5,2 \mathrm{mg} / \mathrm{dl}$ e 5,5 $\mathrm{mg} / \mathrm{dl}$, para o consumo de frutas e hortaliças, respectivamente. Os resultados destes estudos indicaram a necessidade de controle dietético para redução nos riscos de doenças cardiovasculares.

Como outros alimentos, a carne bovina tem uma variedade de ácidos graxos, saturados e insaturados. O ácido oléico (18:1), ácido pamítico (16:0) e o esteárico são os predominantes. Uma porção de $80 \mathrm{~g}$ de carne possui mais ácidos graxos monoinsaturados que saturados e uma pequena quantidade de poiinsaturados (MORGAN et al. 1993).

Estudo de MILLS et al. (1992) mostrou diferenças no conteúdo nutricional entre carne de bovinos tratados com ração à base de silagem de milho ou alfafa e ração à base de soja e peixe. Foi testado o músculo Longuissimis dorsi e aquelas carnes provenientes de animais tratados com silagem de milho e alfafa não apresentaram influência significativa nas quantidades individuais de ácidos graxos. Porém, ácidos graxos poliinsaturados totais estava, em maior quantidade naquela carne de animal tratado com milho que aquela de animal tratado com alfafa. A carne de animal tratado com peixe, tinha maior conteúdo de ácido palmitato e menor conteúdo de ácido esteárico $(p<0,5)$ que a carne de animal tratado com soja. FRENCH et al. (2000) encontraram resultados semelhantes.

Os cortes da carne brasileira têm menores quantidades de gordura, conseqüência de técnicas de produção desenvolvidas para obtenção de gado com 
melhor qualidade nutricional. É o caso do gado zebu - cruzamento de Bos taurus $x$ Bos indicus, criado em pasto e abatido entre 24 e 36 meses - cujos cortes cárneos magros (contendo cerca de $10 \%$ de gordura) desossados, representam $63 \%$, e as carnes com até $20 \%$ de gordura (peito, costela e retalhos) representam $12 \%$ do peso da carcaça. Os $25 \%$ restantes são de ossos, cartilagens, tendões, aponevroses e aparas gordas (FELÍCIO et al. 1999). Já o gado taurino - origem européia - tipicamente criado na Europa, Estados Unidos, Argentina e Uruguai, tem proporção elevada de gordura, especialmente entremeada em músculo (LAZZARINI NETO 1995; STRADIOTTI 2002 ).

Quase toda gordura dos cortes magros pode ser separada com faca, antes ou depois do preparo. A inclusão de $200 \mathrm{~g}$ dessa carne nas dietas, contribui com 12 a $16 \mathrm{~g}$ de gordura, cerca de $7 \%$ de calorias de gordura bovina numa dieta de $2000 \mathrm{kcal}$. Aliado a isso, menos da metade dos ácidos graxos da carne bovina é do tipo saturado (MILLS et al. 1992).

O teor de gordura marmórea da carne (quantidade de gordura intramuscular) é influenciado diretamente pela idade do animal, pois o abatimento quando muito jovem não fornece tempo de acúmulo de gordura em depósitos intramusculares. Porém, as preferências do consumidor variam, e os norte americanos preferem nivel de marmoreio maior que os consumidores da Europa, América Latina e Austrália (SAINZ 1996). 


\subsection{Fatores que influenciam as características sensoriais do produto final}

No que diz respeito à qualidade da carne bovina, a idade de abate elevada, somada à alta velocidade de resfriamento das carcaças tornam a carne brasileira escura no ato da compra e rígida no prato do consumidor. Aspectos genéticos e nivel de estresse do animal também contribuem para a textura da carne (FELÍCIO 1994).

O respeito ao rigor mortis, promovendo um tratamento adequado à carne bovina é essencial para aumentar a qualidade e aceitação da mesma, já que seu atributo mais importante é a maciez. O problema é que, após o abate do animal, o músculo continua com capacidade de contração até esgotar reservas de ATP (trifosfato de adenosina). Este período é chamado rigor mortis. Durante este período, as células musculares obtêm energia por glicólise, resultado da produção de ácido láctico e redução do pH. Quando a temperatura cai rapidamente, antes do esgotamento do ATP, as fibras se contraem violentamente, permanecendo com sarcômero com menor comprimento e com maior dureza. Isto acontece quando o matadouro excede o tempo na refrigeração de carcaças, especialmente quando existe baixo conteúdo de gordura (PRICE \& SCHWEIGERT 1994).

Outra maneira de se avaliar a maciez é pela atividade da calpastatina, enzima inibidora proteolitica da calpaína, que tem-se relacionado com idade e maciez. Níveis aumentados de atividade calpastatina tem sido associada com redução de maciez e, sugere-se que sua inibição de proteólise miofibrilar, durante 
a vida do animal, pode, parcialmente, mostrar diferenças da textura (CREWS 1996). Em estudo realizado por SHACKELFORD et al. (1994), encontraram atividade de calpastatina associada favoravelmente com taxa de crescimento, gordura entremeada. A medida da atividade da calpastatina é, no entanto, de alto custo e demorada. Apesar disso, as informações da genética molecular são uma alternativa para a indústria melhorar a aceitação da carne pelo consumidor.

De acordo com MORGAN et al. (1993), o zinco, presente em alta concentração no músculo de bovinos, é inibidor da calpaína, o que pode contribuir para a redução da maciez da carne. Estes mesmos autores estudando o efeito da castração e do rigor mortis na palatabilidade encontraram menor maciez relacionada a alta atividade de calpastatina, no período pós abate de bovinos castrados.

GEESINK et al. (2000) estudaram o efeito da temperatura do músculo durante o período de pré rigor e pós rigor (não tardios) na maciez da carne, proteólise pós abate, atividade do sistema calpaína, capacidade de retenção de água e cor. A carne foi estocada à temperaturas de 5 a $35^{\circ} \mathrm{C}$, durante a noite, por 16 horas, após o abate e limpeza da carcaça. Posteriormente, durante 14 dias, esta carne foi estocada a $2^{\circ} \mathrm{C}$. A incubação acima de $25^{\circ} \mathrm{C}$, durante a noite, afetou negativamente a maciez e proteólise pós abate, pelo efeito da temperatura na contração muscular e atividade do sistema calpaína. 
Os programas de melhoria genética de animais, tradicionalmente priorizavam o seu crescimento e desenvolvimento, porém, como o consumidor tem se tornado mais consciente da necessidade de cuidados com a saúde, a ênfase à composição da carne é, hoje, importante objeto de estudos. A origem genética, hereditariedade e o fenótipo influenciam na conformação da carcaça do animal e qualidade final da carne. Estudos têm mostrado a estimativa da hereditariedade através da força de cisalhamento da carne, medida no aparelho Warner-Bratzler e textura no painel sensorial (VAN VLECK et al. 1992; SHACKELFORD et al. 1994; GREGORY et al. 1995). GREGORY et al. (1995) e VAN VLECK et al. (1992) indicaram que a correlação de hereditariedade e textura, medida no painel sensorial é baixa a moderada e positiva. Apesar disso, vários estudos de composição genética de textura ainda são necessários, já que a literatura sugere que o método Warner-Bratzler é moderadamente confiável (CREWS et al. 1996). A importância da estimativa de hereditariedade na determinação de gordura entremeada na carne é mostrada em estudos de vários autores (LAMB et al. 1990, WOODWARD et al. 1992, VAN VLECK et al. 1992, MARSHALL1994).

A raça bovina Nelore, possui bom rendimento de carcaça - cerca de $70 \%$ - e, como característica da própria raça, menos gordura entremeada. CROSS et al. (1984) avaliaram maciez em animais das raças Simmmental, Angus e Hereford. Aqueles animais da raça Simmmental tinham menos gordura subcutânea, sendo considerada raça produtora de carne magra. Já as carcaças de animais das raças Angus e Hereford tinham maior quantidade de gordura entremeada - marmoreio e consequentemente, melhor aceitação pelos avaliadores sensoriais. Este é um 
animal com carne marmorizada, com 3 a $6 \mathrm{~mm}$ de gordura, considerada apropriada para o mercado externo europeu e o interno. WHIPPLE et al. (1990) encontraram resultados semelhantes ao estudo de CROSS et al. (1984). Testaram maciez nas carnes de animais resultantes de cruzamento das raças Hereford e Angus e encontraram alta aceitação destas, avaliadas em painel sensorial.

A idade do animal tem relação direta com teor de gordura intramuscular da carne pois, se o animal é abatido muito jovem, não há acúmulo excessivo de gordura em depósitos intramusculares. O bovino precoce é abatido, geralmente, com 2 anos ou menos, sendo a metade do tempo de abatimento do bovino adulto. Com esta idade já existe conformação de carcaça desejável e qualidade muscular (SAINZ 1996; ALMEIDA 1998; PIRES 1998).

De acordo com estudo conduzido por JEREZ-TIMAURE \& LEIDENZHUERTA (1996) o teor de gordura entremeada de carnes de bovinos MestiçosZebu (Zebu e Brahman), além de Pardo Suíço e Holstein em base Zebu, facilitou o processo de cocção, reduzindo o tempo de preparo. Quando avaliada a variável sexo, encontraram menor tempo de cocção para novilhas de 3 e 4 anos de idade em comparação com aquelas de 2 anos de idade. Porém, esta tendência não foi observada em animais machos, nos quais a cocção teve menor tempo de duração para animais mais novos ( 3 anos de idade).

Estudo realizado por BOOLEMAN et al. (1997) sugeriu que a percepção do consumidor perante a maciez de carnes é variável e, se pudesse degustar 
antes de comprar, estaria disposto a pagar um preço maior por uma carne com garantia de maciez, considerada por ele de melhor qualidade. SAVELL et al. (1989), MORGAN et al. (1991) e JONES et al. (1992) também encontraram resultados semelhantes em seus estudos, quando mostraram que os consumidores conseguem perceber diferentes graus de maciez dentro de cada categoria.

Apesar disso, a textura ainda não é medida diretamente na carcaça para determinar grau de qualidade. A relação entre gordura e maciez é baixa e, quanto maior a quantidade de gordura entremeada, menor a probabilidade do consumidor perceber a carne como seca, sem sabor (CREWS 1996).

Existe, portanto, variação nos parâmetros culinários referentes à presença de gordura intramuscular e idade fisiológica do animal. Estes dados mostram a possibilidade de aplicação de estratégias de Marketing, orientando o consumidor sobre maciez, justificando preços diferenciados.

Os bovinos têm crescimento em tamanho até os 7 anos de idade ou mais, porém, grande parte do desenvolvimento muscular se completará aos 2 anos de vida. A partir deste ponto, a taxa de deposição de gordura aumenta. Haverá conversão em gordura da maior parte dos alimentos fornecidos ao animal e esta gordura terá deposição intramuscular, subcutânea, ao redor dos órgãos (rins e coração), cavidade pélvica e parede abdominal (gordura interna) em grande proporção. Existe assim uma relação inversa entre as porcentagens de gordura e 
proteína. A carcaça de boa classificação, independente do critério utilizado, não deve ultrapassar o percentual de $25 \%$ de gordura referente à composição corporal (BARBOSA 1997).

Estudos indicam correlação positiva $(r=0,23)$ entre maciez da carne bovina e aumento da idade do animal, entre 5 e 30 meses de idade. Porém, a partir desta faixa etária, a maciez diminui com o aumento da idade do animal. Esta influência é determinada pelo aumento da quantidade e estrutura físico-química do colágeno (maior número de ligações cruzadas). O bovino precoce apresenta, portanto, vantagem em relação à esta característica, quando comparado com adulto (SAINZ 1996; WHEELER et al. 2002).

O colágeno é o principal componente de todos os tecidos conectivos podendo-se encontrar inúmeros tipos distintos geneticamente em à relação caracterização bioquímica. Sua molécula é composta de três cadeias polipeptídicas, chamadas de cadeias $\alpha$, com sequências repetidas da forma gly-X$Y$ ao longo de seu comprimento, onde $X$ é normalmente o aminoácido prolina e, $Y$, hidroxiprolina ou outro qualquer (PRICE \& SCHWEIGERT 1994). É um fator importante no processo de maciez de uma carne e contribui para a dureza das carnes devido à sua influência no processo de encolhimento e perda de suco durante a cocção. É o principal componente da maciez que pode ser modificado pelo aquecimento. As características que influenciam são a quantidade, tipo e insolubilidade de colágeno presentes na carne (LIRA 1997; LIRA et al. 1999; 
McCORMICK 1999; NISHIMURA et al. 1999; PHILLIPS et al. 2000). Em média, $22 \%$ do colágeno intramuscular em bezerros de 8 a 9 semanas é solúvel em água quente; em bovinos de 10 meses de idade, aproximadamente $12 \%$ e, em torno de 4\%, é solúvel em vacas adultas (LIRA 1997).

Em estudo conduzido por POHLMAN et al. (1997), analisando o efeito de diferentes métodos de cocção sobre a textura de músculo pectoralis e longissimus dorsi, encontraram maior força exercida pelo texturômetro no músculo pectoralis, considerando seu maior teor de colágeno insolúvel.

As proporções de gordura e aponevroses de algumas carnes faz com que, mesmo com preço mais baixo, a aquisição desta carne não seja uma boa opção de escolha, já que o aproveitamento será menor (FELíCIO 1999).

A implementação de controle sistêmico de qualidade é fundamental para assegurar ao consumidor final, que a carne comprada atenda às especificações de qualidade, seja do ponto de vista sensorial (cor, quantidade e distribuição de gordura, aparência geral, maciez, aroma, sabor, suculência), nutricional (teor protéico, baixa densidade calórica) e de segurança (ausência de agentes patogênicos e resíduos químicos) (BLISKA \& GONÇALVES 2000).

Com o aumento do interesse e necessidade da promoção de saúde da população em geral é importante que as recomendações dietéticas sejam feitas em conjunto com a educação nutricional e empreendimento do setor de toda a 
cadeia mercadológica da carne. Esta tendência é mostrada por 30\% da população que se preocupa com menores teores de gordura da carne. Desta forma, mudanças no tipo de carne consumida, através de possibilidades de escolha relativa à qualidade nutricional e organoléptica podem ser necessárias para atingir as recomendações dietéticas, de maneira satisfatória.

A exclusão total de carnes da alimentação não é fundamentada pela literatura. Ela aumenta o risco de deficiências nutricionais, além de promover baixa adesão à dieta, não sendo, portanto, indicada. Isto reforça a necessidade de utilização de carne magra para o tratamento e prevenção de doenças cardiovasculares, anemias e outras implicaçōes nutricionais, o que justifica a atenção para obtenção de carcaça bovina com reduzido conteúdo de gordura.

Torna-se, portanto, de grande importância o desenvolvimento de pesquisas visando contribuir para o desenvolvimento de estratégia nacional de segurança alimentar, derrubando mitos e definindo critérios, visando a utilização de carnes de boa qualidade nutricional e aceitação, menor conteúdo de gordura e maior giro de mercado. Os estudos de aceitação da carne de bovino precoce, além da caracterização nutricional, mostram-se necessários, a medida que se enquadram na tendência de consumo atual. 


\section{2 - OBJETIVOS}

\section{1- Objetivo Geral}

Avaliar a qualidade nutricional e características sensoriais das carnes de bovino precoce e adulto cruas e grelhadas

\section{2- Objetivos Específicos}

a) Analisar a composição da carne de bovino precoce crua e grelhada em relação ao teor de umidade, proteina, gordura total, gordura saturada, gordura monoinsaturada, gordura poliinsaturada, colesterol, carboidrato, valor energético total, ferro e zinco

b) Analisar características de preferência do sabor, suculência e maciez das carnes de bovino precoce e adulto grelhadas

c) Analisar característica de textura das carnes de bovino precoce e adulto grelhadas 


\section{3- MATERIAL E MÉTODOS}

\section{1- Local de estudo}

Foram realizadas análises de nutrientes, sensoriais e de textura nos laboratórios do Centro de Química de Alimentos e Nutrição Aplicada/Instituto de Tecnologia de Alimentos (ITAL), Centro de Tecnologia de Alimentos (SENAI/CETAL) e Centro Universitário do Triângulo (UNIT), localizados em Campinas - SP e Uberlândia - MG.

\section{2- Coleta de dados}

\subsection{1- Matéria prima}

A coleta de dados foi feita durante o período de 6 meses. As carnes de bovino precoce analisadas foram cedidas pelo "Núcleo de produtores de bovino precoce do estado de Minas Gerais". Os animais $(n=3)$ utilizados eram do sexo masculino e castrados, raça Nelore, criados a pasto e terminados em confinamento, tinham idade de 24 meses, 3 dentes definitivos, média de peso de $245 \mathrm{~kg}$, conformação de carcaça convexa, com média de $3,5 \mathrm{~mm}$ de gordura, medida na altura da $12^{\mathrm{a}}$ costela, sobre 0 músculo serrátil dorsal caudal, caracteristicas estas concordantes com aquelas citadas por ANJOS (1992). 
De acordo com ANJOS (1992), o sistema de tipificação de carcaças de bovinos foi instituído no Brasil, através do Departamento Nacional de Inspeção de Produtos de Origem Animal (DIPOA), do Ministério da Agricultura, após 20 anos de pesquisa, atendendo à necessidade de se oferecer um produto identificado. Foi oficializado pela portaria ministerial n. 612 de 5/10/89. É um sistema prático e composto de parâmetros de sexo, maturidade, conformação, acabamento, sendo que a maturidade fisiológica é obtida pelo exame dos dentes. Se necessário, o exame é complementado pela observação da calcificação das cartilagens das apófises espinhosas das vértebras torácicas. O bovino precoce é o animal jovem, de qualquer sexo, sendo o macho castrado ou não, apresentando no máximo as pinças e os $10^{\circ}$ médios da segunda dentição, sem ter tido perda dos $20^{\circ}$ médios e com peso mínimo de $210 \mathrm{~kg}$ de carcaça morta (obtido na sala de matança, logo após o abate) para machos (em alguns estados, $225 \mathrm{~kg}$ ) e $180 \mathrm{~kg}$ para fêmeas, mínimo de camada de gordura de 1 a $3 \mathrm{~mm}$ de espessura medida nos seguintes locais:

na altura da $6^{\text {a }}$ costela, sobre o músculo grande dorsal, em sua parte dorsal; na altura da $9^{a}$ costela, sobre o músculo grande dorsal, em sua parte ventral; na altura da $12^{\mathrm{a}}$ costela, sobre o músculo serrátil dorsal caudal; região lombar e no coxão, para complementação.

Ainda, o bovino adulto pode ser macho castrado ou fêmea, com mais de 6 dentes incisivos da segunda dentição, peso mínimo de $225 \mathrm{~kg}$ para macho e $180 \mathrm{~kg}$ para fêmea. 
O abate foi realizado no frigorífico Mata Boi (MG), sob fiscalização do Serviço de Inspeção Federal (SIF), seguindo-se, portanto, padrões sanitários recomendados. Os animais foram submetidos a estimulação elétrica. Para evitar o endurecimento da carne, (cold shortening) as carcaças permaneceram a temperatura de $10^{\circ} \mathrm{C}$ por 10 horas após a sangria.

\subsection{2 - Composição centesimal da carne}

Foram retiradas 3 amostras (obtidas de 3 animais) de carne de bovino precoce para análise crua e 3 amostras de carne de bovino precoce para análise

grelhada, tendo sido utilizado o músculo longuissimus dorsi. As amostras de $100 \mathrm{~g}$ cada foram retiradas da parte central do músculo e foram conservadas congeladas em sacos de polietileno.

As amostras foram analisadas quanto aos teores de umidade, proteina, gordura total, gordura saturada, gordura monoinsaturada, gordura poliinsaturada, colesterol, carboidrato, valor energético total, ferro e zinco.

\subsubsection{1 - Teores de umidade}

Os teores de umidade foram determinados através da técnica descrita nas Normas Analíticas do Instituto Adolfo Lutz (ADOLFO LUTZ 1985). 
Os materiais utilizados foram: estufa, dessecador de vidro, cápsulas de porcelana, balança analítica e pinça.

A técnica utilizou os seguintes passos:

1. manutenção da estufa em $105^{\circ} \mathrm{C}$ com colocação das cápsulas de porcelana, por 3 horas;

2. retirada das cápsulas e colocação em dessecador até atingirem temperatura ambiente;

3. pesagem das cápsulas, em balança analítica;

4. pesagem de $10 \mathrm{~g}$ da amostra nas cápsulas taradas com aquecimento, durante 5 horas, em estufa a $105^{\circ} \mathrm{C}$;

5. resfriamento em dessecador até a temperatura ambiente e pesagem das cápsulas, em balança analítica, juntamente com a amostra seca.

\subsubsection{2 - Teores de proteína}

O teor de proteína foi determinado pelo método Kjeldhal para determinação do nitrogênio total, seguindo as Normas Analíticas do Instituto Adolfo Lutz (INSTITUTO ADOLFO LUTZ 1985).

A determinação da proteína foi realizada através da técnica de microKjeldhal e utilizado fator de correção de $6,25 \mathrm{XN}$ para todos os materiais. 
Os materiais utilizados foram: bloco digestor de proteínas, balança analítica, aparelho de micro-Kjeldhal, tubo para digestão de proteínas, erlenmeyer, pipetas, sulfato de cobre, sulfato de potássio, ácido sulfúrico concentrado, ácido bórico, indicador de Kjeldhal e ácido clorídrico $(0,02 \mathrm{~N})$.

A técnica utilizou os seguintes passos:

1. pesagem de $50 \mathrm{mg}$ da amostra dessecada e transferência para o tubo de digestão, com adição, em capela, dos seguintes reagentes no tubo de digestão: $40 \mathrm{mg}$ de sulfato cúprico (CuSO4), $2 \mathrm{~g}$ de sulfato de potássio (K2SO4) e $3 \mathrm{ml}$ de ácido sulfúrico ( $\mathrm{H} 2 \mathrm{SO} 4)$;

2. digestão do tubo no bloco digestor a $350^{\circ} \mathrm{C}$ até a mudança da solução de preto para esverdeado; após digestão, adição de aproximadamente $10 \mathrm{ml}$ de água destilada, com agitação;

3. inserção de $5 \mathrm{ml}$ de ácido bórico $(\mathrm{H} 3 \mathrm{BO} 3)$ e 3 gotas do indicador de Kjeldhal em erlenmeyer à parte; destilação das amostras no aparelho de micro-Kjeldhal e colheita do destilado em erlenmeyer acima mencionado, até o alcance de $50 \mathrm{ml}$ de volume do destilado;

4. titulação com ácido clorídrico $(\mathrm{HCl} 0,02 \mathrm{~N})$ até mudança de cor (roxo-azulado).

Obs. : preparo do branco: apenas adição dos reagentes no tubo de digestão.

Cálculo:

$\% \mathrm{~N}=\underline{(\mathrm{m} \mid \mathrm{HCl}-\mathrm{Xm|HCl} \text { branco }) \cdot 0,02 \mathrm{~N} \cdot 14,007 \cdot 100 \text { fator de correção ácido }}$

mg de amostra

$\% P=\% N \cdot 6,25$ 


\subsubsection{3 - Teores de gordura total, ácidos graxos, colesterol}

As gorduras foram extraidas e mensuradas através de coluna seca, segundo a técnica de análise descrita por MARMER \& MAXWELL (1981).

Os materiais utilizados foram: coluna de vidro $35 \mathrm{~mm} \times 30 \mathrm{~cm}$ de comprimento; solventes (diclorometano e metanol na proporção 9:1); recheio para coluna de vidro de $10 \mathrm{~g}$ de fosfato dicálcio dihidratado e celite 545 na proporção $1: 9 ; 20 \mathrm{~g}$ de sulfato de sódio anidro e $15 \mathrm{~g}$ de celite 545 ; graau e pistilo $750 \mathrm{~g}$; proveta 200ml; balão de fundo chato; erlenmeyer, nitrogênio; estufa; dessecador de vidro; lã de vidro; funil e colher de sopa.

\section{A técnica seguiu os passos abaixo:}

1. colocação da lã de vidro na coluna, adição de $10 \mathrm{~g}$ da mistura CaHPO4/celite empacotado com firmeza; pesagem de $10 \mathrm{~g}$ de amostra com transferência para o graau; adição de $20 \mathrm{~g}$ de $\mathrm{Na2SO} 4$ anidro, misturando até formar um pó e, $15 \mathrm{~g}$ de celite, continuando a misturar e transferência para a coluna com ajuda de um funil e uma colher de sopa; empacotamento para formar uma camada uniforme;

2. adição, com proveta, de $200 \mathrm{ml}$ de solvente, coleta do extrato com balão de fundo chato e mensuração do volume recolhido; inserção do erlenmeyer em estufa regulada para $105^{\circ} \mathrm{C}$ durante 3 horas; resfriamento em dessecador até a temperatura ambiente; pesagem dos erlenmeyers; 
3. pipetagem de $10 \mathrm{ml}$ do extrato; evaporação em corrente de N2; colocação em estufa por 2 horas; resfriamento em dessecador até temperatura ambiente; pesagem em balança analitica.

Para realizar as dosagens de ácidos graxos, utilizou-se extrato coletado de lipideos totais. A extração e separação foram feitas de acordo com MARMER \& MAXWELL (1981). Foram metilados $10 \mathrm{mg}$ de lipídeos de acordo com MORRISON \& SMITH (1964). As amostras metiladas foram analisadas em cromatógrafo à gás - Chrompack CP9002.

Os materiais utilizados foram: pipetas, aparelho de rotovapor, nitrogênio, solução de BF3, 14\% em metanol, hexano para cromatografia líquida, água destilada, cromatógrafo à gás.

O procedimento foi o seguinte:

1. pipetagem de $10 \mathrm{ml}$ do extrato e evaporação em rotovapor; adição de $1 \mathrm{ml}$ de BF3 (a solução de BF3 a $20 \%$ foi diluída para $14 \%$ em metanol para a utilização na metilação) e 0,5 ml de ácido heptanóico; adição de gás N2 e fechamento do tubo; aquecimento a $100^{\circ} \mathrm{C}$ em banho-maria por 7,5 minutos; resfriamento por 20 minutos;

2. adição de $1 \mathrm{ml}$ de água destilada e $2 \mathrm{ml}$ de hexano para cromatografia; coleta da camada superior; injeção em cromatógrafo à gás. 
Obs.: o padrão utilizado para a leitura no cromatógrafo à gás foi o Lipid Standard Sigma - Fatty acid methyl ester mixture \# 189 - 19.

Para realizar as dosagens de colesterol, utilizou-se também extrato coletado de lipídeos totais. A determinação dos teores de colesterol foi realizada segundo método de BOHAC et al. (1988).

Os materiais utilizados foram: $\mathrm{KOH}$, etanol, hexano, gás nitrogênio, ácido sulfúrico concentrado, ácido acético glacial, sulfato ferroso, vortex, banho-maria, espectrofôtometro.

O procedimento foi o seguinte:

1. preparo de $\mathrm{KOH}$ a $12 \%$ em etanol a $90 \%$; pipetagem de $3 \mathrm{ml}$ do extrato, com evaporação total em gás nitrogênio, inserção de $10 \mathrm{ml}$ de $\mathrm{KOH}$ a $12 \%$, saponificação da solução em banho-maria a $80^{\circ} \mathrm{C}$, com agitação por 15 minutos; adição de $5 \mathrm{ml}$ de água destilada e esfriamento;

2. adição de $10 \mathrm{ml}$ de hexano p.a. (agitação no vortex); espera de separação das fases; coleta da parte superior e reserva;

3. adição de $+10 \mathrm{ml}$ de hexano p.a. na porção inferior restante e agitação; coleta da parte superior e mistura com a parte reservada; pipetagem de $4 \mathrm{ml}$ do hexano e evaporação total; 
4. acréscimo de $6 \mathrm{ml}$ de solução saturada de sulfato ferroso em ácido acético glacial e agitação; acréscimo de $2 \mathrm{ml}$ de ácido sulfúrico concentrado; agitação; espera de esfriamento por 15 minutos;

5. realização de leitura no espectrofôtometro UV - VIS a 490nm.

Obs.: o padrão de colesterol utilizado para a curva foi o Cholesterol C - 8253 Sigma.

\subsubsection{4 - Teores de carboidratos}

A determinação do valor de carboidrato foi feita por diferença. Uma vez determinados todos os outros micro e macronutrientes, os valores percentuais foram subtraídos de 100 e o valor restante resultou no percentual de carboidratos. Para isto, realizou-se também a determinação de cinzas, utilizando-se os seguintes materiais: estufa regulada a $105^{\circ} \mathrm{C}$, balança analítica, mufla regulada a $550^{\circ} \mathrm{C}$, cadinho de porcelana, bico de Bunsen, triângulo de porcelana, tripé e pinça. A técnica utilizada, segundo as Normas Analíticas do Instituto Adolfo Lutz (INSTITUTO ADOLFO LUTZ 1985), considerou os seguintes passos:

1. colocação dos cadinhos de porcelana em estufa regulada para $105^{\circ} \mathrm{C}$, durante 3 horas; resfriamento em dessecador até temperatura ambiente para pesagem; pesagem dos cadinhos; 
2. pesagem de $2 \mathrm{~g}$ de amostra dessecada nos cadinhos; queima das amostras nos cadinhos, aos poucos, em bico de gás; com a transformação do produto em massa de carvão, transferência dos cadinhos para a mufla, deixando-os por 12 horas;

3. Retirada dos cadinhos da mufla e transferência para o dessecador; resfriamento até a temperatura ambiente; pesagem em balança analitica

\subsubsection{5 - Valor energético total}

Para o cálculo de valor energético, utilizou-se o fator 4 , a ser multiplicado tanto pelo total protéico quanto pelo de carboidrato encontrados (em g) e fator 9 para lipídeos (g) (WATER \& MERRILL 1963).

Os valores obtidos foram comparados com aqueles citados por PEARSON \& DUTSON (1990), já que os autores utilizam carne de animal da raça Nelore e músculo longissimus dorsi, 6 amostras de carne para a avaliação dos nutrientes considerados. Este foi, portanto, parâmetro mais próximo para comparação aos valores encontrados neste trabalho. Estes dados completos não foram encontrados em tabelas nacionais de composição de alimentos, o que inviabilizou a comparação. 


\subsubsection{6 - Teores de ferro e zinco}

Foram realizadas medições em triplicata dos minerais ferro e zinco, tanto para a carne do bovino precoce crua quanto cozida. As amostras (200g) foram incineradas em forno a $450^{\circ} \mathrm{C}$, por 12 horas, de acordo com método descrito por CUNNIF (1998). As cinzas foram dissolvidas em $2,5 \mathrm{ml}$ de concentrado de ácido nítrico e diluído para $50 \mathrm{ml}$ com água deionizada. Foi utilizado o espectrômetro ICP - OES system, modelo BAIRD 2000, para quantificação dos minerais (IMO INDUSTRIES INC. BAIRD ANALYTICAL INSTRUMENTS DIVISION 1990).

\subsection{3- Amostras para análise sensorial}

Foram retirados $2,0 \mathrm{~kg}$ de carne de 3 animais, localizados na parte central do músculo, que foram subdivididos em bifes de $100 \mathrm{~g} \mathrm{e}$, imediatamente após preparo, novamente subdivididos em amostras de $30 \mathrm{~g}$, para procedimento de comparação das análises organolépticas, de acordo com indicação de DAMÁSIO \& SILVA (1996) e ANZALDÚA-MORALES (1994). Esta coleta de amostras ocorreu tanto para o bovino precoce (sendo os mesmos animais utilizados para amostragem das outras análises), quanto para o bovino adulto (animal com 48 meses, obtido através de mesmo sistema de criação, tendo recebido os mesmos cuidados de inspeção e tratamento pós abate). 
O método de cocção escolhido foi calor seco (grelhado), já que é normalmente utilizado para cortes do quarto traseiro do bovino, de acordo com ORNELLAS (2001), e é o método mais comumente empregado e aceito para cocção de bifes (POHLMAN et al. 1997). Utilizou-se como corte - tanto para a carne de bovino precoce quanto para a carne do bovino adulto - o contra-filé (músculo longissimus dorsi). Foram cortados em pedaços uniformes, de $100 \mathrm{~g}$ cada, no sentido contrário à orientação das fibras musculares. As carnes foram temperadas apenas com sal para não terem seu sabor mascarado - na mesma medida para cada amostra (1g). As carnes não foram batidas e não receberam qualquer outro tratamento físico ou químico de amaciamento, para se evitar alteração das propriedades de textura. A temperatura de pré aquecimento da panela foi de $150^{\circ} \mathrm{C}$, de acordo com orientação de BERRY \& ABRAHAM (1995). Utilizou-se temperatura final de cocção de $70^{\circ} \mathrm{C}$ (JEREZ-TIMAURE \& HUERTALEIDENZ 1996) e serviu-se em temperatura média de $50^{\circ} \mathrm{C}$, medida através de termômetro agulha da marca FILIZOLA, e de acordo com orientações de SALEH \& AHMED (1998). As carnes de bovino precoce e adulto foram cozidas concomitantemente, sendo o tempo, em média, de 3 minutos, para o adulto e 5 minutos para o precoce. Foi considerado ponto de cocção ideal quando havia mudança de cor para marron claro, sem saída de sangue. 


\subsection{4- Análise sensorial}

Para análise de características de sabor, suculência e maciez, foram realizados testes com equipe treinada (alunos, professores e funcionários do Centro Universitário do Triângulo), em laboratório apropriado, isento de ruídos e odores. Foi realizado o método de diferença (prova discriminatória), teste de comparação pareada ou pareado-diferença, que tem como objetivo determinar se duas ou mais amostras diferem entre si, de acordo com o avaliador. As provas discriminatórias não pretendem conhecer a sensação subjetiva produzida pelo alimento em uma pessoa, mas estabelecer se existe diferença ou não entre duas ou mais amostras. No caso do teste de comparação pareada, apenas duas amostras são comparadas em relação a alguma característica sensorial e estabelecida qual das amostras possui maior intensidade da propriedade testada. Este método é bastante sensivel, não existe necessidade de muitas instruções para os degustadores e número grande de amostras. Neste teste cada provador recebeu duas amostras codificadas e foi solicitado a identificar a amostra que apresentava maior intensidade de uma característica sensorial (ANEXO 1) (DAMÁSIO \& SILVA 1996; ANZALDÚA-MORALES 1994).

Participaram da análise sensorial 40 individuos treinados, de ambos os sexos, faixa etária de 18 a 50 anos, que foram conduzidos a cabines individuais (ANEXOS 1 e 2). Os atributos considerados foram maciez, suculência e sabor (ANEXO 3). 
Os degustadores lavaram a boca entre uma amostra e outra com água à temperatura ambiente e estas foram deglutidas. Não houve comunicação entre eles (SENAI 1994).

Os dados foram coletados no período da manhã, às $9: 30$, com intervalo de pelo menos duas horas após o café da manhã do degustador e, no período da tarde, às 15:30, pelo menos duas horas após o almoço, para reduzir possibilidade de erro metodológico (SENAI 1994).

As amostras para os testes foram apresentadas aos degustadores em recipientes de louça, mesmo tamanho, cor branca, limpos, sem odor ou sabor interferentes e talheres de inox. Os degustadores foram treinados para avaliar primeiro o odor e depois o sabor e sempre as amostras da esquerda para direita. As amostras foram codificadas ao acaso e a ordem de apresentação foi sorteada e controlada em ficha separada (não acessivel ao degustador) para não induzir vício de código e erro de posição (SENAI 1994; STONE \& SIDEL 1985). Foram apresentadas três posições para cada amostra, para cada degustador.

Os critérios utilizados para exclusão de degustadores foram ajuda no preparo das amostras, gripe, aversão à carne e fumantes ou mascadores de chicletes uma hora antes da degustação (DAMÁSIO \& SILVA 1996; SENAI 1994).

A temperatura da amostra, mantida por banho-maria, foi de $45^{\circ} \mathrm{C}$, que é a temperatura recomendável para avaliar pratos quentes em relação a sabor e 
aroma, de acordo com SENAI (1994). De acordo com DAMÁSIO \& SILVA (1996) temperaturas acima deste valor podem diminuir a sensibilidade para o sabor.

\subsection{5- Análise objetiva}

A análise foi realizada através do método objetivo de medida da maciez da carne, utilizando-se o analisador de textura TA.XT2i, da Stable Micro Systems, cela do tipo Warner Bratzler, com software Texture Expert. Para determinar força de cisalhamento foram utilizadas amostras do músculo longuissimus dorsi, com medidas de $1 \mathrm{~cm}^{2}$ de área de seção transversal e $2 \mathrm{~cm}$ de comprimento (PUGA et al. 1999 e POSTE et al. 1993), tendo sido repetidas 3 vezes. Considerou-se distância de $48 \mathrm{~mm}$, sendo a velocidade do teste $3 \mathrm{~mm} / \mathrm{s}$.

\section{3- Variáveis de estudo}

- Umidade

- Proteína

- gordura total

- gordura saturada

- gordura monoinsaturada

- gordura poliinsaturada

- Colesterol

- Carboidrato 
- Valor energético total

- Ferro

- Zinco

- Maciez

- Suculência

- Sabor

- Textura

\section{4- Análise de dados}

Para as análises estatísticas dos dados, utilizou-se 0 teste $t$ de Student (BERQUÓ et al., 1981; CUNNIF 1998). Para comparar as variáveis umidade, valor energético total, colesterol, proteínas, gordura total, saturada e poliinsaturada das carnes cozidas de bovino precoce, entre carne crua e cozida, e quanto aos teores de ferro e zinco. Este teste também foi utilizado para comparar a maciez avaliada pelo texturômetro em carnes cozidas e cruas de bovino precoce e bovino e adulto. O teste de diferença entre proporções (BUSSAB \& MORETTIN 2002) foi utilizado para detectar diferenças significativas entre as proporções de avaliadores que consideraram carne de bovino precoce e bovino adulto para as caracteristicas maciez, sabor e suculência.

Para análise dos dados referentes à análise sensorial, foi considerada a amostra indicada pela maioria dos degustadores como sendo a mais intensa na 
característica avaliada (maciez, suculência e sabor). Foi anotado o número de provadores que indicaram essa amostra como a mais intensa e verificado o número mínimo de respostas para o número total de testes aplicados, utilizandose o nivel de significância de $5 \%$.

Foram utilizados os programas estatísticos STATDISK (TRIOLA 1999) e SASISTAT (1990).

\section{5- Questões éticas}

Todos os participantes do estudo foram informados sobre o objetivo do estudo e estavam de acordo com o termo de consentimento livre e esclarecido, segundo resolução no 196, de 10 de outubro de 1996 do CONSELHO NACIONAL DE SAÚDE que regulamenta pesquisas envolvendo seres humanos (ANEXO 4). 


\section{4 - RESULTADOS}

\section{1 - Composição nutricional}

A tabela 1 mostra dados referentes à composição centesimal média das carnes de bovino adulto precoce cruas. $O$ valor energético total é menor para a carne de bovino precoce, indicando diferença de $30 \%$ em relação à carne de bovino adulto. A diferença existe também para os valores da gordura total, saturada, monoinsaturada, poliinsaturada e colesterol.

Tabela 1: Composição centesimal média e desvio-padrão das carnes de bovino adulto e precoce cruas ${ }^{\star}$

\begin{tabular}{|c|c|c|}
\hline Nutriente & Carne de bovino adulto & $\begin{array}{c}\text { Carne de bovino } \\
\text { precoce }\end{array}$ \\
\hline $\begin{array}{l}\text { Valor energético } \\
\text { total (kcal) }\end{array}$ & $188,00 \pm 2,35$ & $133,22 \pm 1,81$ \\
\hline Umidade (g) & $71,73 \pm 1,16$ & $77,7 \pm 0,95$ \\
\hline Carboidratos (g) & - & - \\
\hline Proteínas (g) & $22,90 \pm 1,48$ & $25,00 \pm 1,12$ \\
\hline Gordura total (g) & $10,22 \pm 0,57$ & $3,30 \pm 0,58$ \\
\hline -Saturada (g) & $3,99 \pm 0,24$ & $1,21 \pm 0,23$ \\
\hline -Monoinsaturada (g) & $5,81 \pm 0,36$ & $1,99 \pm 0,28$ \\
\hline -Poliinsaturada (g) & $0,42 \pm 0,05$ & $0,10 \pm 0,01$ \\
\hline Colesterol (mg) & $127,00 \pm 1,10$ & $50,00 \pm 0,98$ \\
\hline
\end{tabular}


A tabela 2 mostra dados referentes à composição centesimal média das carnes de bovino adulto e precoce cozidas. Houve redução média de $66 \%$ do teor de colesterol e redução de $64 \%$ de gordura total da carne de bovino precoce quando comparada à carne de bovino adulto. A redução do valor energético total da carne de bovino precoce cozida foi de $32 \%$, em média, em relação à carne de bovino adulto

Tabela 2: Composição centesimal média e desvio-padrão das carnes de bovino adulto e precoce cozidas *

\begin{tabular}{|lcc|}
\multicolumn{1}{|c}{ Nutriente } & Carne de bovino adulto** & Carne de bovino \\
Valor energético total & $228,00 \pm 4,33$ & precoce \\
(kcal) & & $155,40 \pm 2,20$ \\
Umidade (g) & $60,90 \pm 1,10$ & $59,30 \pm 0,84$ \\
Carboidratos (g) & $27,95 \pm 2,23$ & $29,00 \pm 1,44$ \\
Proteinas (g) & $12,93 \pm 0,73$ & $4,40 \pm 0,98$ \\
Gordura total (g) & $5,43 \pm 0,66$ & $1,85 \pm 0,43$ \\
-Saturada (g) & $6,90 \pm 0,71$ & $2,35 \pm 0,49$ \\
-Monoinsaturada (g) & $0,60 \pm 0,08$ & $0,20 \pm 0,03$ \\
-Poliinsaturada (g) & $184,00 \pm 1,64$ & $66,00 \pm 1,22$ \\
Colesterol (mg) & & \\
\hline
\end{tabular}

$n=3$

** De acordo com PEARSON \& DUTSON (1990)

Quando comparadas as médias das carnes cozidas de bovinos adultos e precoces para as variáveis valor energético total, gordura total, gorduras saturada, mono e poliinsaturada, foram encontradas diferenças 
estatisticamente significativas entre as médias $(p<0,001)$. Para proteína, as médias encontradas não apresentaram diferenças estatisticamente significativas (tabela 3).

Tabela 3: Teste t de Student de médias das carnes cozidas de bovinos adulto e precoce para as variáveis analisadas.

\begin{tabular}{|c|c|c|}
\hline Variáveis & Valor Calculado $\left(t_{c}\right)$ & Prob $t_{c}>t_{c r i t}{ }^{\star \star}$ \\
\hline $\begin{array}{l}\text { Valor energético } \\
\text { total (kcal) }\end{array}$ & $-27,0788^{b}$ & $0,0000^{6}$ \\
\hline Proteínas $(\mathrm{g})$ & $0,7238^{a}$ & $0,4926^{a}$ \\
\hline Gordura total (g) & $-14,9049^{b}$ & $0,0000^{b}$ \\
\hline -Saturada (g) & $-8,3929^{b}$ & $0,0001^{b}$ \\
\hline -Monoinsaturada (g) & $-8,4433^{b}$ & $0,0001^{b}$ \\
\hline -Poliinsaturada (g) & $-8,1408^{b}$ & $0,0001^{b}$ \\
\hline Colesterol (mg) & $-108,9422^{b}$ & $0,0000^{b}$ \\
\hline
\end{tabular}

"nível de significância $(\alpha)=0,05$

*teste considerado significativo quando a probabilidade do valor de $t$ calculado for maior do que o valor de $t$ crítico e (Prob $t_{c}>t_{c r i t}$ ) for menor do que 0,05

$a=$ médias estatisticamente iguais

$b=$ médias estatisticamente diferentes

A tabela 4 mostra dados referentes ao conteúdo médio e desvio padrão de ferro e zinco em carnes crua e cozida de bovinos precoce e adulto. Para os dois minerais, os teores na carne do bovino precoce foram superiores para a carne cozida. 
Tabela 4: Conteúdo médio e desvio-padrão de ferro e zinco em carnes crua e cozida de bovinos precoce e adulto *
Tipo de carne
Ferro
Zinco

Carne de bovino $13,86 \pm 0,94^{\mathrm{a}} \quad 32,86 \pm 1,02$

precoce crua

Carne de bovino $18,55 \pm 0,32^{b} \quad 44,54 \pm 0,43$

precoce cozida

Carne de bovino $4,63 \pm 0,87^{c} \quad 4,20 \pm 0,74$

adulto crua

Carne de bovino $6,55 \pm 0,56^{d} \quad 6,20 \pm 0,43$

adulto cozida

${ }^{*} n=3$ (amostras de diferentes animais)

letras iguais $=$ médias estatisticamente iguais

letras diferentes $=$ médias estatisticamente diferentes

De acordo com dados mostrados na tabela 5, houve diferença estatisticamente significativa entre o conteúdo de ferro e zinco, comparando-se as carnes de bovino precoce crua e cozida

Tabela 5: Teste t para carne crua e cozida dos bovinos precoces

\begin{tabular}{|lcc|}
\hline Nutriente & Valor Calculado $\left(\boldsymbol{t}_{c}\right)$ & Prob $\boldsymbol{t}_{c}>\boldsymbol{t}_{\text {crit }}{ }^{* *}$ \\
\hline Ferro & $-8,1808$ & 0,0012 \\
Zinco & $-18,2760$ & 0,0001 \\
\hline
\end{tabular}

* nivel de significância $(\alpha)=0,05$

*teste considerado significativo quando a probabilidade do valor de $t$ calculado for maior do que o valor de $t$ crítico e (Prob $t_{c}>t_{c r i t}$ ) for menor do que 0,05 (médias estatisticamente diferentes).

Quando foram comparados os dados de teores de ferro e zinco, em carnes crua e cozida de bovino precoce e bovino adulto, encontraram-se 
diferenças estatisticamente significativas (tabela 6). Para os dois minerais, os teores na carne de bovino precoce foram superiores.

Tabela 6: Teste $t$ dos teores de ferro e zinco em carnes crua e cozida de bovinos precoce e adulto.

\begin{tabular}{|lcl|}
\hline \multicolumn{1}{|c|}{$\begin{array}{c}\text { Nutrienteltipo de } \\
\text { preparação }\end{array}$} & Valor Calculado $\left(t_{c}\right)$ & Prob $t_{c}>t_{c r i t}{ }^{* *}$ \\
\hline Fe (carne cozida) & 32,2252 & \\
Fe (carne crua) & 13,1709 & 0,0000 \\
Zn (carne cozida) & 109,2017 & 0,0002 \\
Zn (carne crua) & 39,3923 & 0,0000 \\
\hline
\end{tabular}

*nivel de significância $(\alpha)=0,05$

**teste considerado significativo quando a probabilidade do valor de $t$ calculado for maior do que o valor de $t$ crítico e (Prob $\mathbf{t}_{\mathrm{c}}>\mathbf{t}_{\text {crit }}$ ) for menor do que 0,05 (médias estatisticamente diferentes).

\section{2 - Análise sensorial}

De acordo com os resultados apresentados na tabela 7 , em relação às características maciez e sabor, $85 \%$ dos degustadores indicaram a carne de bovino precoce como a mais macia e saborosa, quando comparada com a carne do bovino adulto. Ainda, a carne de bovino precoce foi escolhida como a mais suculenta, pela maioria dos degustadores $(77,5 \%)$.

Tabela 7: Freqüências dos avaliadores para maciez, suculência e sabor.

\begin{tabular}{|lcc|}
\hline \multicolumn{1}{|c|}{ Variáveis } & Adulto & Bovino precoce \\
\hline Maciez & $6(15 \%)$ & $34(85 \%)$ \\
Suculência & $8(22,5 \%)$ & $32(77,50 \%)$ \\
Sabor & $6(15 \%)$ & $34(85 \%)$ \\
\hline
\end{tabular}


A tabela 8 mostra a existência de diferenças significativas entre as carnes de bovino precoce e adulto, relativas às características de maciez, suculência e sabor

Tabela 8: Teste de diferença de proporções para as características avaliadas pelos 40 avaliadores.

\begin{tabular}{|lcc|}
\multicolumn{1}{c}{ Variáveis } & Valor Calculado $\left(\boldsymbol{Z}_{\boldsymbol{c}}\right)$ & Prob $\mathbf{Z}_{\mathbf{c}}>\mathbf{Z}_{\text {crit }}{ }^{* *}$ \\
Maciez & $-6,2610$ & 0,0000 \\
Suculência & $-5,3666$ & 0,0000 \\
Sabor & $-6,2610$ & 0,0000 \\
\hline
\end{tabular}

*nivel de significância $(\alpha)=0,05$

**teste considerado significativo quando a probabilidade do valor de $t$ calculado for maior do que o valor de $Z$ crítico e (Prob $Z_{c}>Z_{c r i i}$ ) for menor do que 0,05 (proporções estatisticamente desiguais)

\section{3 - Análise de textura}

A tabela 9 mostra dados referentes à força utilizada no texturômetro, para carnes de bovino precoce e adulto cruas e cozidas. Os resultados apontam utilização de maior força necessária ao cisalhamento das amostras de carne crua. A força usada para o cisalhamento da carne de bovino adulto foi superior àquela usada na carne de bovino precoce, em ambas as condições.

Tabela 9: Força $(\mathrm{kgf} / \mathrm{g})$ utilizada no texturômetro, em carnes de bovinos precoce e adulto*
Tipo de carne
Bovino precoce
Bovino adulto

Crua

$2,58 \pm 0,05$

$4,21+0,07$

Cozida
$2,01 \pm 0,03$
$3,44 \pm 0,06$

* 3 amostras 
De acordo com as análises dos dados referentes à textura, medida pelo texturômetro, foram encontradas diferenças entre as texturas avaliadas para as carnes de bovino adulto e precoce. Estas diferenças foram estatisticamente significativas de acordo com as comparações das carnes de bovino precoce entre si (crua e cozida), carnes de bovino adulto entre si (crua e cozida) e bovino precoce com bovino adulto (crua e cozida) (tabela 10).

Tabela 10: Teste t de Student para diferença entre médias, quanto a textura avaliada pelo texturômetro.

\begin{tabular}{|c|c|c|}
\hline Comparaçōes & Valor Calculado $\left(t_{c}\right)$ & Prob $t_{c}>t_{\text {crit }}{ }^{* *}$ \\
\hline $\begin{array}{l}\text { Precoce crua } \\
\mathrm{X}\end{array}$ & $-32,8195$ & 0,0000 \\
\hline Adulto crua & & \\
\hline $\begin{array}{c}\text { Adulto cozida } \\
\mathrm{X}\end{array}$ & 36,9224 & 0,0000 \\
\hline Precoce cozida & & \\
\hline
\end{tabular}

*nivel de significância $(\alpha)=0,05$

*teste considerado significativo quando a probabilidade do valor de $t$ calculado ser maior do que $o$ valor de $t$ crítico e (Prob $t_{c}>t_{c r i t}$ ) for menor do que 0,05 (médias estatisticamente desiguais) 


\section{5- DISCUSSÃO}

\subsection{Composição nutricional}

Neste estudo, quando comparadas as carnes cruas de bovino precoce e adulto, foram encontrados valores diferentes para umidade, com a carne de bovino precoce apresentando, em média, 10\% mais água que a carne de bovino adulto (tabela 1). Já UZCÁTEGUI et al. (1999) não encontraram diferenças significativas de umidade entre animais precoces e adultos, apresentando média de $73 \%$ de água para estas carnes cruas.

Tanto a carne de bovino precoce quanto a de adulto apresentaram maiores teores de umidade quando cruas. As diferenças de umidade encontradas neste estudo, após a cocção, mostram a maior tendência da carne de animais mais jovens em perder água neste processo, pela demanda de maior tempo de preparo, provavelmente relacionada à menor quantidade de gordura condutora de calor. Para a carne bovino precoce, a perda de umidade após cocção foi de $24 \%$, enquanto para a carne de bovino adulto, a perda foi de $15 \%$ (tabelas 1 e 2 ). Apesar desta perda de água proporcionalmente maior, a carne de bovino precoce teve valores de umidade similares aos da carne de do animal adulto, após o processo de cocção. Ocorreu, portanto, desidratação através processo de cocção, para os dois tipos de carnes estudadas, fato já esperado. 
A suculência da carne cozida pode ser detectada através da percepção da umidade durante as primeiras mordidas, produzidas pela liberação rápida de fluidos e/ou através da liberação lenta da umidade e ao potencial efeito estimulador da gordura na produção de saliva. Portanto, como não houve diferença de umidade entre as carnes cozidas estudadas, a umidade neste caso, não influenciaria a suculência final dos dois tipos de carnes, como seria esperado para carnes com maior teor de umidade após a cocção.

Houve variação na composição nutricional da carne de bovino precoce analisada neste estudo. Foram encontradas diferenças significativas em relação aos teores de calorias e nutrientes das carnes crua e cozida de bovino precoce quando comparadas às carnes de bovino adulto crua e cozida (tabelas 1 e 2).

As carnes de bovino adulto e precoce não apresentaram diferenças significativas relativas ao teor de proteínas, tanto para carnes cruas quanto cozidas (tabela 3). Este dado é concordante com aquele citado por PEARSON \& DUTSON (1990), avaliando carnes com teores diferentes de gordura.

Porém, houve diferença significativa entre as carnes de bovino precoce e adulto cruas e cozidas para a variável calorias, sendo a carne do animal precoce menos calórica. Esta porcentagem calórica da carne de bovino precoce em comparação com o bovino adulto apresentou diferença de mais de $70 \mathrm{kcal}$ (tabela 2), em média, o que favorece sua utilização em dietas 
hipocalóricas. Considerando que, a ingestão média de $200 \mathrm{~g}$ de carne de bovino precoce perfazem apenas $12 \%$ das necessidades calóricas de um adulto (2500 kcal) e, praticamente $100 \%$ das recomendações de proteína $($ RDA/89 $=58-$ 63g/dia) (NRC 1989), considera-se que esta seja uma carne de boa qualidade nutricional, desfavorecendo, portanto, os indicadores de sobrepeso da população brasileira.

De acordo com os dados do SCVCF (1999) de que 35 milhões de nordestinos consomem per capita de carne bovina de $5 \mathrm{~kg} / \mathrm{ano}$, a indicação do uso de carne de bovino precoce poderia ser uma alternativa para consumo mais adequado de nutrientes importantes, especialmente ferro, veiculados por este alimento. Porém, o preço da carne de bovino precoce é, em média, $30 \%$ mais alto que o preço da carne do bovino adulto. Considerando o preço da carne do bovino adulto, os dados do ANUALPEC (2002) indicam que no ano de 2001 a média de preço de varejo do Contra Filet, na cidade de São Paulo, era de $R \$ 5,31$, sendo o Filet Mignon com preço de $R \$ 9,34$ e, Picanha, $R \$ 10,65$. Dos cortes menos macios, localizados na parte dianteira do bovino, o Acém tinha preço de $R \$ 3,02$ e, o músculo, $R \$ 2,68$. Estes custos inviabilizam a compra da carne da parte traseira do bovino adulto, considerada "nobre" por famílias de menor poder de compra, aumentando também a inviabilidade da compra da carne de bovino precoce. Porém, a diversificação da produção fazse necessária perante diferentes mercados, com hábitos alimentares e preocupação com a saúde, além de diferentes padrões econômicos. Além disso, a carne do bovino precoce tem maior rendimento e qualidade nutricional, considerando menores teores de gordura. 
As análises de gordura da carne de bovino precoce encontradas neste estudo mostram que existem diferenças significativas quando comparadas à carne de bovino adulto (tabela 3). Em relação aos conteúdos de gordura total, saturada, mono e poliinsaturada, foram encontrados valores significativamente menores para a carne de bovino precoce, tanto crua quanto cozida, quando comparada com a carne de bovino adulto. Ainda, os valores menores de gordura encontradas na carne de bovino precoce analisada no presente estudo, mostram uma carne mais adequada à prevenção e controle de doenças cardiovasculares. O conteúdo médio de colesterol total encontrado na carne de bovino precoce foi quase um terço menor que o do bovino adulto, além de menor concentração de gordura saturada. Considerando que a principal intervenção dietética para tratamento e prevenção de dislipidemias é a redução da ingestão de alimentos ricos neste nutriente, a carne do bovino precoce mostra-se como opção viável. Desta forma, a redução drástica ou substituição de carnes por outros alimentos protéicos de origem vegetal não seria necessária.

De todos os princípios nutritivos da carne, a gordura é a que está submetida a flutuações maiores. A carne que possui muita gordura (bovino adulto) tem muita energia, porém, dependendo do músculo da carne magra essas proporções podem variar bastante $(0,5$ a $10 \%)$. A carne de bovino precoce cozida analisada aqui apresentou valor de gordura total de 4,40 $( \pm$ 0,98)g, em 100g (tabela 2). Por estes teores de gordura total obtidos, a carne de bovino precoce pode ser considerada magra. E comparando-se o conteúdo de gordura total de diferentes tipos de carnes cozidas com a carne de bovino 
precoce cozida analisada neste estudo, constata-se seu teor reduzido de gordura total. De acordo com dados de PEARSON \& DUTSON (1990), a carne de frango magra tem $8 \%$ de gordura total, a carne de peixe (tainha, truta), $12 \%$, e a carne de porco, $12 \%$, sendo todas com valores mais elevados que a carne de bovino precoce do presente estudo.

A carne de animais jovens ( 2 anos no máximo) contém, em geral mais água e menos gordura que as dos adultos (mais de 2 anos) e são mais propensas à deposição de gordura intermuscular que a deposição de gordura subcutânea e intramuscular. Esta é também a razão porque a carne de animais jovens não apresenta marmorização (PRICE \& SCHWEIGERT 1994). Este processo de marmorização descrito, dificulta a retirada do excesso de gordura da carne, impossibilitando torná-la mais magra, através de processos de pré preparo. A carne avaliada no presente estudo foi obtida da raça bovina Nelore, que possui menor teor de gordura entremeada no músculo e rendimento de carcaça de $70 \%$, considerado muito bom. Porém, as carnes de animais mais velhos têm menor tempo de cocção, pela maior quantidade de gordura apresentada que tem função condutora do calor. JEREZ-TIMAURE \& HUERTA-LEIDENZ (1996) obtiveram maiores tempos de cocção nas carnes de animais mais jovens, com pouca gordura marmórea, com diferença de 27 minutos entre novilhas de 2 a 4 anos. Para os animais machos, estes autores não encontraram diferenças.

Este estudo encontrou baixos valores calóricos, em relação aos lipideos, caracterizando a carne de bovino precoce estudada como magra e 
adequada tanto para normocolesterolêmicos, quanto para pessoas com altos teores de colesterol. Estes dados sugerem a utilização deste tipo de carne, de maneira mais freqüente na vida dos consumidores, de qualquer faixa etária.

O teor de colesterol encontrado na carne de bovino precoce cozida, com média de 66mg, incentiva por si só, a inclusão deste tipo de carne nas dietas típicas hipocolesterolêmicas. Considerando uma ingestão de alimentos fontes de colesterol, com fornecimento máximo recomendado de $300 \mathrm{mg} / \mathrm{dia}$, a ingestão de $200 \mathrm{~g}$ deste tipo de carne cozida torna-se viável, já que atingiria mais ou menos $50 \%$ da necessidade de colesterol. A carne de bovino precoce pode assim ser indicada, portanto, em casos patológicos, além de dietas sem restrições lipídicas severas.

Existem grandes variações entre os valores de colesterol encontrados na literatura. Estas diferenças ocorrem, provavelmente, em função da dieta, raça, alimentação e dos cortes animais, além da metodologia de medição empregada. Este dado sugere a necessidade de análises mais uniformes e de tabelas de composição de alimentos caracterizando a produção de carne no pais

As técnicas de preparo das carnes também têm influência para o consumo, como apresentado por FLYNN et al. (1982) que constataram, em estudo controlado por um período de três meses, com adultos jovens, de ambos os sexos, que não havia diferenças significativas para colesterol e suas 
frações, com o consumo de frango ou peixe, bife de boi, carne de porco, quando estas carnes tinham suas peles e gorduras aparentes retiradas.

Os reduzidos teores de gordura saturada e insaturada do animal precoce podem resultar na orientação para estudos de prevenção e tratamento e doenças cardiovasculares. Para redução das taxas destas doenças, tem se estimulado a redução na ingestão de alimentos com altos teores de ácidos graxos saturados, que estimula a produção de lipoproteínas de baixa densidade (LDL - colesterol) (GOTTO 1990; LARYSSE \& GARCIA-CASAL 1997; GUILLAUME et al. 2000).

Em uma dieta de $2500 \mathrm{Kcal}$, a recomendação de ingestão de calorias advindas de gordura total seria de $25 \%$ (625 Kcal). Tomando como base a ingestão de $200 \mathrm{~g}$ de carne de bovino precoce cozida, esta porcentagem seria, em média, de 12,7, considerando que outros alimentos fontes de gordura fariam parte desta dieta.

Os resultados sobre conteúdo de zinco na carne de bovino precoce crua encontrados neste estudo mostram quantidades 8 vezes maiores quando comparadas com a carne do bovino adulto (tabela 4). $O$ ferro neste estudo, de maneira semelhante ao zinco, apresentou resultados bastante satisfatórios, levando em consideração a necessidade de ações preventivas mais eficazes na prevenção e combate de anemias, comuns em vários grupos populacionais. 
Ainda, houve diferença significativa entre teor de ferro das carnes de bovino precoce cozida e crua (tabela 6), como era esperado. Este resultado é semelhante àquele encontrado no estudo de SNYDER et al. (1994) que verificaram aumento na concentração de ferro em carne cozida $(2,90 \mathrm{mg} / 100 \mathrm{~g})$ comparada à carne crua $(1,95 \mathrm{mg} / 100 \mathrm{~g})$.

De acordo com Guia alimentar para crianças menores de 2 anos (MS 2002), a quantidade de carne recomendada para esta faixa etária é de 50 a $80 \mathrm{~g} /$ dia. O presente estudo mostra a possibilidade de se ingerir menores porções de carne, condizentes com a capacidade gástrica de uma criança, porém, com alto conteúdo de ferro (RDA89 $=6$ a $10 \mathrm{mg} / \mathrm{dia})$. Desta forma possibilita-se a redução do risco de anemia ferropriva, especialmente em crianças com baixo nível sócio econômico e/ou baixa ingestão de carnes.

Considerando dados de estudo realizado por SILVA (2000) que encontrou maiores chances de anemia em crianças de 12 a 24 meses, cuja renda familiar era igual ou inferior a 1 salário mínimo, a carne de bovino precoce forneceria conteúdo maior de ferro em uma porção menor, facilitando o acesso a este nutriente.

Considerando uma ingestão de $200 \mathrm{~g}$ de carne de bovino precoce cozida, obtemos mais de $100 \%$ da recomendação de ferro $($ RDA $89=10-$ $15 \mathrm{mg} / \mathrm{dia})$ e do zinco $(\mathrm{RDA} / 89=12-15 \mathrm{mg} / \mathrm{dia})$ recomendados, descartando qualquer possibilidade de inadequação da ingestão em condições fisiológicas consideradas normais. 


\subsection{Análise sensorial}

Através da avaliação do painel sensorial detectou-se diferenças significativas de aceitação e a carne de bovino precoce foi considerada a mais macia, saborosa e suculenta, comparando-se com a carne de bovino adulto. Parece que o consumidor brasileiro ainda não definiu suas preferências em relação ao tamanho e a qualidade dos cortes, porém, rejeita a carne de coloração escura e com excesso de gordura e aprecia a maciez.

Os degustadores escolheram como mais suculenta, a carne com menor teor de gordura (bovino precoce), provavelmente pela conjugação de preferências de sabor e maciez. A umidade não variou quando comparadas carnes já cozidas de bovino precoce e bovino adulto, mostrando que não houve influência do conteúdo de água na suculência dos dois tipos carnes. Estudo conduzido por MILLS et al. (1992) analisou a palatabilidade através de painel sensorial e não encontrou diferenças entre textura e suculência para carnes de animais tratados com diferentes tipos de dietas, porém encontrou melhor aceitação de carnes com menores teores de gordura, de maneira semelhante ao presente estudo. Porém, estes dados diferem daqueles apresentados por estudos de JENNINGS et al. (1978) e depois de CROSS et al. (1984) que encontraram carcaça de bovinos com maior teor de gordura, apresentado maior maciez e suculência. De acordo com estes autores o conteúdo de gordura pode ter sido o principal mantenedor da sensação de suculência, sendo expressa pela liberação rápida de fluidos percebidos nas primeiras 
mordidas. Outra possibilidade teria sido o baixo poder de proteção conferido pelas carcaças magras contra endurecimento da carne.

Resultados de estudos realizados por JENNINGS et al. (1978), SPANIER et al. (1997), TAYLOR \& KOOHMARAI (1998) mostram a gordura sucutânea parece formar uma barreira e permite uma redução gradual no declínio da temperatura do músculo, durante o resfriamento da carcaça. Este processo previne encurtamento das fibras musculares, maximizando a palatabilidade.

A carne de bovino precoce possui menores quantidades de colágeno, tendo, portanto, sua maciez aumentada em relação à carne de bovino adulto. Os dados encontrados no presente trabalho são concordantes com FELÍCIO (1994), mostrando menor maciez para carne de bovino adulto. O músculo estudado aqui - longissimus dorsi - possui menores quantidades de colágeno quando comparados àqueles cortes que necessitam de processo térmico lento e úmido, onde o colágeno é prepoderante. De acordo com JEREZ-TIMAURE \& HUERTA-LEIDENZ (1996), o fator maturidade, portanto, é importante porque a qualidade organoléptica da carne, principalmente a maciez, piora com o avanço da idade, possivelmente em decorrência de alterações que ocorrem no colágeno intramuscular.

No Brasil, a população, seleciona a maciez como uma das características mais importantes de escolha da carne, independente do nível sócio econômico, desfavorecendo a venda do produto com características 
negativas de maciez. O menor teor de gordura também atrai o consumidor (LAZZARINI NETO 1995; SHACKELFORD et al. 1997). A carne de bovino precoce analisada neste estudo agrega maciez, pela precocidade, além de menor teor de gordura, facilitando, portanto, sua aceitação.

A qualidade exigida e percebida pelo consumidor não deve ser definida tecnicamente sem antes perguntar este mesmo consumidor. Esta qualidade depende do produto e evolui com as caracteristicas pessoais (experiência com o produto, educaçāo, idade) e sociais (valores veiculados pela midia)

\subsection{Análise de textura}

A força utilizada pelo texturômetro foi menor para a carne de bovino precoce, mostrando concordância com os resultados da avaliação subjetiva de maciez. Os resultados deste estudo, sob a análise do texturômetro, indicam diferenças significativas entre as carnes de bovino precoce e adulto, tanto cruas quanto cozidas. Estes dados confirmam aqueles publicados na literatura por JENNINGS et al. (1978) e CROSS et al. (1984), comparando textura de carne de animais mais novos com aqueles mais velhos

Outro estudo. conduzido por EILERS et al. (1996) avaliou a influência do tempo pós abate sobre a maciez da carne. Encontrou que, gradativamente, até $\circ 24^{\circ}$ dia pós abate, a força utilizada no texturômetro Warner-Bratzler 
diminuía, utilizando tratamento diferentes para abate. Os resultados destes autores mostram mais um aspecto que pode influenciar a textura da carne.

As carcaças estudadas aqui receberam tratamento elétrico, tendência esta percebida nos frigoríficos de abate tanto de bovinos precoces quanto adultos. De maneira semelhante ao presente estudo, ROEBER et al. (2000) estimularam o músculo longissimus dorsi de animais estocados por período de 7 dias, à temperatura de $5^{\circ} \mathrm{C}$ e obtiveram resultados positivos em relação à maciez da carne. Outros estudos têm ressaltado a importância comercial de processos de estimulação elétrica no tratamento de carcaças bovinas, já que promovem grau de maturidade desejável e melhoria de coloração da carne quando comparados com outras carcaças sem tratamento (TATUM et al. 1999; ROEBER et al. 2000; den HERTOG-MEISCHKE et al. 2000).

CROSS et al. (1984) estudaram a influência da maturidade sexual, sexo, idade e estimulação elétrica de carcaça na palatabilidade, em animais com idades de abate de 12,15 e 18 meses. Mostraram que a maturidade sexual tinha pouca influência na textura da carne. O músculo longuissimus dorsi de animais com 18 meses apresentava maior maciez em relação ao músculo dos animais mais jovens. Ainda, aqueles animais mais jovens tiveram melhores respostas à melhoria de maciez, quando submetidos à estimulação elétrica. 


\section{CONSIDERAÇÕES FINAIS}

No Brasil, mesmo sendo considerada de baixo preço em relação a outros países, a carne bovina é de difícil aquisição pelos trabalhadores. Acredita-se que a melhoria na distribuição de renda possa modificar esta situação, elevando o consumo per capita anual de $35 \mathrm{~kg}$ para $55 \mathrm{~kg}$, semelhante ao da Argentina e Uruguai. Este fato demandaria maior produtividade e com qualidade (CEZAR \& EUCLIDES FILHO 1996). Apesar do custo mais alto, a carne de bovino precoce apresenta maior rendimento e qualidade nutricional. Ela é amplamente reconhecida como uma das principais fontes de proteinas de alto valor biológico, minerais - principalmente ferro e zinco - e vitaminas do complexo B, sendo um alimento de alta concentração nutricional e baixo valor calórico.

Existe uma necessidade de se produzir carne de melhor qualidade. A falta de controle e cuidados na produção, transporte, comercialização das carnes reduz a qualidade do sabor, textura e outras características importantes de consumo. A modernização de toda a cadeia de produção e mercadológica é essencial para melhoria da matéria prima.

A indústria deseja melhorar a textura e qualidade da carne, o que é importante para a adesão do consumidor à compra mais freqüente deste produto e para o estabelecimento de valores comerciais diferentes, de acordo com as características de tratamento diversificadas. 
Levando em consideração que as características intrínsecas do animal não são fáceis de se identificar no momento de aquisição carne, é necessário o treinamento dos consumidores e comerciantes de carne para a identificação da mesma. Um canal de informações sobre as características do animal pode traduzir-se através da rastreabilidade, tendência no mundo todo.

A cadeia da carne bovina precisa de dinamismo e desenvolver e promover cortes e produtos de fácil preparo para tender ao novo estilo de vida da população, considerando consumidores de poderes aquisitivos diversificados.

Para aumentar a aceitação de dietas com teores reduzidos de gordura, mudanças na seleção tradicional de alimentos pode ser orientada, ensinando-se à população, técnicas de seleção, pré preparo e preparo de alimentos, além de mostrar a compatibilidade do uso da carne nestas dietas e a permissão do uso de grande variedade de alimentos.

A relação entre dieta e saúde aumenta a necessidade das indústrias realizarem análises dos alimentos comercializados. Uma importante ferramenta é, portanto, a determinação da composição de alimentos para o estabelecimento de controles analíticos.

Tendo e vista os dados acima, estratégias devem ser implementadas com a finalidade de promover a adequação nutricional das dietas de vários países, especialmente aqueles com alimentação mista ou basicamente 
vegetariana. Estas podem englobar o envolvimento das comunidades, através da participação em pesquisas cientificas, considerando a comunicação em nutrição e estratégias de marketing social, cujo objetivo é a mudança de atitude e comportamentos alimentares, de maneira a se manterem sustentáveis. 


\section{7-RECOMENDAÇÕES}

De acordo com os resultados deste estudo recomenda-se:

- Estudos de qualidade e composição da carne de diferentes raças de animais, já que no Brasil existem inúmeros cruzamentos entre elas.

- Estudos comparativos de qualidade e composição da carne de animais com diferentes sistemas de criação (pasto livre e confinamento) para atingir melhores resultados nutricionais.

- Estudos de fatores culinários que afetam as características sensoriais da carne.

- Padronização de métodos de avaliação e melhoria da textura de carnes, considerando toda a cadeia de produção e comercialização da carne.

- Mais estudos sobre conhecimento do perfil do consumidor de carne em diferentes regiões do Brasil, especialmente aquelas ainda não estudadas

- Estabelecimento de consciência da ingestão de carne de qualidade pela população, para o consumo a niveis aceitáveis pelas recomendações nutricionais vigentes.

- Orientação ao consumidor sobre o real conteúdo nutricional dos diferentes tipos de carnes. 


\section{8- CONCLUSÕES}

Este estudo mostrou importantes características nutricionais e sensoriais da carne de bovino precoce, considerada de alta qualidade sob o ponto de vista comercial.

Em relação à carne de bovino adulto, a carne de bovino precoce analisada apresentou menores teores de gorduras, especialmente colesterol.

Os teores de ferro e zinco mostraram-se significativamente maiores para a carne de bovino precoce quando comparada com a de bovino adulto.

A carne de bovino precoce foi considerada, pelo método subjetivo, mais macia, suculenta e saborosa, em relação à carne de bovino adulto.

Através do método objetivo, a carne de bovino precoce esteve mais macia que a do bovino adulto. 


\section{REFERÊNCIAS ${ }^{1}$}

Almeida AD. Novilho precoce: do produtor ao consumidor, todo mundo sai ganhando. Revista PROMMEPE (Programa Matogrossense de Melhoramento da Pecuária) 1998.

Anjos JB. Tipificação de carcaças. Hig Alim 1992; 6 (24): 15-17.

Anuário Estatístico de Produção Animal (ANUALPEC): FNP Consultoria e Comércio. São Paulo; 2002.

Anzaldúa-Morales A. La evaluación sensorial de los alimentosen la teoria y la práctica. España: Acribia. 1994u

Barbosa PF. Raças e cruzamentos para produção de novithos precoces. Encontro nacional dos confinadores e $5^{\circ}$ Encontro estadual do novilho precoce; 1997 - agosto 7-8; Brasil - Campinas .

Bellizzi MC, Franklin MF, Duthie GG, James WPT. Vitamin E and coronary heart disease: the European paradox. Eur J Clin Nutr 1994; 48: 822-31.

Berry BW \& Abraham HC. Sensory, shear force and cooking properties of commercially processed ground beef patties. Food Quality and Preference 1995; 7 (1): 55-9.

\footnotetext{
${ }^{1}$ Normas referentes à Faculdade de Saúde Pública/USP
} 
Berquó ES, Souza JMP, Gotlieb SLD. Bioestatística. São Paulo: EPU; 1981.

Black MM. Zinc deficiency and child development. Am J Clin Nutr 1998; 68 Suppl: $464-9$.

Bleil SI. O padrão alimentar ocidental: considerações sobre a mudança de hábitos no Brasil. Cadernos de debate/Revista do Núcleo de Estudos e Pesquisas em Alimentação (NEPA/UNICAMP) 1997; volume VI: 1-25.

Bliska FMM \& Gonçalves JR. Qualidade na cadeia produtiva da carne bovina: elaboração e implementação de um sistema de controle. Revista Carne 2000; 276:11-12.

Booleman SJ, Booleman SL, Miller RK, Taylor JF, Cross HR, Wheeler TL, Koohmaraie M, Shackelford SD, Miller MF, West RL, Johnson DD, Savell JW. Consumer evaluation of beef of know categories of tenderness. J Anim Sci 1997; 75: 1521-24.

Brooks JC, Belew JB, Griffin DB, Gwartney BL, Hale DS, Henning WR, Johnson DD, Morgan JB, Parrish FC, Reagan JO, Savell JW. National Beef Tenderness Survey - 1998. J Anim Sci 2000; 78: 1852-60.

Bussab WO \& Morettin P. Estatística Básica. Saraiva; 2002. p. 323-54. 
Cade J, Calvert C, Barrett J. How could the BSE crisis affect nutrient intake? Comparison of beef and non-beef eating meat eaters from the UK women's cohort study. Eur J Clin Nutr 1998; 52: 151-2.

Campos, H. Estatística experimental não-paramétrica. $2^{a}$ ed. Piracicaba: ESALQ/USP; 1976.

Cezar IM \& Euclides Filho K. Novilho precoce: reflexos na eficiência e economicidade do sistema de produção. EMBRAPA-CNPGC 1996; Documentos, 66 .

Cleeman JI \& Lenfant C. The National Cholesterol Education Program: progress and prospects. JAMA 1998; 280:2099-104.

Costa B. Alianças: conciliar interesses é fundamental. DBO Rural - Anuário pecuária de corte. 2000, n. 231.

Crews Jr. DH. Targets for beef cattle improvement: selection for meat quality. Proceedings: beef improvement federation. $28^{\text {th }}$ Research Symposium and Annual Meeting. Birmingham, Alabam. May 15-18, 1996.

Cross HR, Crouse JD, MacNeil MD. Influence of breed, sex, age and electrical stimulation on carcass and palatability traits of three bovine muscles. J Anim Sci 1984; 58 (6): 1358-65. 
Cunnif $P$ (ed.). Official Methods of Analysis of the Association of Official Analytical Chemists. 16 th ed. Virginia. 1998.

Damásio MH \& Silva MAAP. Análise sensorial de alimentos: curso de treinamento. Campinas; 1996. [Apostila do Curso da Fundação Tropical de Pesquisas e Tecnologia " André Tosello" ].

Dayton S, Pearce ML, Goldman H. Controlled trial of a diet high in unsaturated fat for prevention of atherosclerotic complications. Lancet 1968; 16: 1060-2.

Demaeyer EM, Dallman P, Gurney JM, hallberg L, Sood SK, Srikantia SG. Preventing and controlling iron deficiency anaemia through primary health care: a guide for health administrators and programme managers. 1989. (World Health Organization).

den Hertog-Meischke MJA, Smulder FJM van Lotestijn JG, van knapen I. The effect of electrical stimulation on the water-holding capacity and protein denaturation of two bovine muscles. J Anim Sci 75: 118-24.

Denke MA. Role of beef and beef tallow, an enriched source of stearic acid, in a cholesterol-lowering diet. Am J Clin Nutr 1994; 60 Suppl: 1045-95.

Dreesen DW. Hazard Analisys and Critical Control Point systems as a preventive toll. JAMA 1998; 213 (12): $1741-44$. 
Eilers JD, Tatum JD, Morgan JB, Smith GC. Modification of early-postmortem muscle $\mathrm{pH}$ and use of postmortem aging to improve beef tenderness. J Anim Sci $1996 ; 74: 790-98$.

Fabrinni Filho LC \& Silva LF. Complexo avícola e questões sobre hábito alimentar. NEPA/UNICAMP, campinas, 1997.

Food and Agriculture Organization/World Health Organization. Necessidades de energia y proteinas. Ginebra; 1985. (OMS. Serie de relatorios tecnicos, 4).

Felício PE, Carvalho-Rocha JCM, Shibuya CM. Parcerias verticais de carne bovina e serviços de alimentação. Higiene Alimentar 1999; 13 (63): 9-14.

Felício PE. Dois aspectos de competitividade da carne de bos indicus, um positivo, outro negativo. Anais do $1^{\circ}$ congresso Brasileiro das Raças Zebuínas; 1994 out 23-26; cidade da publicação; editora; ano publicação.

Flynn MA, Naumann D, Nolph GB, Krause G, Ellersieck M. Dietary "meats" and serum lipids. Am J Clin Nutr 1982; 35: 935-42.

Fornés NS, Martins IS, Hernan M, Velásquez-Meléndez G, Ascherio. Food frequency consumption and lipoproteins serum levels in the population of na urban area, Brazil. Rev Saúde Pública 2000; 34 (4):380-7. 
Fornés NS, Martins IS, Velásquez-Meléndez G, Latorre MRDO. Escores de consumo alimentar e níveis lipêmicos em população de São Paulo, Brasil. Rev Saúde Pública 2002; 36 (1): 12-8.

French P, Stanton C, Lawless F, O'Riordan EG, Monahan FJ, Caffrey PJ, Moloney AP. Fatty acid composition, including conjugated linoleic acid, of intramuscular fat from steers offered grazed grass, grass silage, or cocetratebased diets. J Anim Sci 2000; 78: 2849-55.

Fujimori E, Shima H, Salum MJL. Consumo alimentar de estudantes universitários do sexo feminino. Rev Esc Enf USP 1986: 20 (2): 115-24.

FUNDO DAS NAÇÕES UNIDAS PARA A INFÂNCIA. Saúde e nutrição das crianças nordestinas: pesquisas estaduais 1987-1992. Brasília; 1995. (UNICEF).

Galeazzi MAM, Domene SMA, Sichieri R. Estudo multicêntrico sobre consumo alimentar. Cadernos de debate/Revista do Núcleo de Estudos e Pesquisas em Alimentação (NEPAUNICAMP) 1997.

Geesink GH, Bekhit AD, Bickerstaffe. Rigor temperature and meat quality characteristics of lamb logissimus muscle. J Anim Sci 2000; 78: 2842-48. 
Germano PML \& Germano MIS. Encefalopatia espongiforme bovina - síndrome da "vaca louca": doença emergente transmissivel por alimentos. Hig Alim 2001; 15 (89): $45-52$.

Gibson RS. Zinc nutrition in developing countries. Nutr Res Rev 1994; 7: 15173.

Gibson RS, Yeudall F, Drost N, Mtitimuni B, Cullinan T. Dietary interventions to prevent zinc deficiency. Am J Clin Nutr 1998; 68 Suppl: 484-7.

Gibson RS \& Ferguson EL. Assessment of dietary zinc in a population. Am J Clin Nutr 1998; 68 Suppl: 430-4.

Golub MS, Takeuchi PT, Keen CL, Hendrickx AG, Gershwin ME. Activity and attention in zinc-deprived adolescent monkeys. Am J Clin Nutr 1996; 64: 90815.

Gotto AM, LaRosa JC, Hunninghake D et al. The cholesterol facts. A sumary of evidence relating dietary fats, serum cholesterol, and coronary heart disease. A joint statement by the Americam Heart Association and the National Heart, Lang and Blood Institute. Circulation 1990; 81: 1721-33.

Gregory KE, Cundiff LV, Koch RM. Genetic and phenotypic (co) variances for growth and carcass traits of purebred and composite populations of beef cattle. J Anim Sci 1995; 73:1920. 
Grunert KG. What's in a steak? A cross-cultural study on the quality perception of beef. Food Quality and Preference 1997; 8 (3): 157-74.

Guillaume M, Lapidus L, Lambert A. Differences in associations of familial and nutritional factors with serum lipids betweem boys and girls: the Luxemburgo Child Study. Am J Clin Nutr 2000; 72: 384-8.

Haile RWC, Hunt IF, Buckley J, Browdy BL, Murphy NJ, Alpers D. Identifying a limited number of foods important in supplying selected dietary nutrients. J Am Diet Assoc 1998; 86: 611-6.

Hegsted DM, McGandy RB, Myers ML, Stare FJ. Quantitative effects of dietary fat on serum cholesterol in man. Am J Clin Nutr 1965; 17: 281-95.

Hegsted DM, Ausman LM, Johnson JA, Dallal GE. Dietary fat and serum lipids: an evaluation of the experimental data. Am J Clin Nutr 1993; 57: 875-83.

Hoeg JM. Evaluating coronary heart disease risk. JAMA 1997; 277: 1387-90.

Hu FB, Stampfer MJ, Manson JE, Ascherio A, Colditz GA, Speizer FE, Hennekens $\mathrm{CH}$, Willett WC. Dietary saturated fats and their food sources in relation to the risk of coronary heart disease in women. Am J Clin Nutr 1999; 70: $1001-8$ 
Imo Industries Inc. baird analytical instruments division. ICP 2000 spectrometer user's guide. Bedford, Massachusetts, 1990.

Instituto Adolfo Lutz. Normas analíticas do Instituto Adolfo Lutz. Métodos físicos e químicos para análise de alimentos, São Paulo, 1985. $3^{\mathrm{a}}$ ed.

James WPT. Nutrition science and policy research: implications for Mediterranean diets. Am J Clin Nutr 1995; 61 Suppl: 1324-8.

Janelle KC \& Barr SI. Nutrient intakes and eating behavior scores of vegetarian and nonvegetarian women. J Am Diet Assoc 1995; 95: 180-6.

Jennings TG, Berry BW, Joseph AL. Influence of fat thickness, marbling and length of aging on beef palatability and shelf-life characteristics. J Anim Sci $1978 ; 4(3): 658-65$.

Jerez-Timaure N \& Huerta-Leidenz N. Factores que afectan la culinaria de bistés del músculo Longissimus de bovinos venezolanos. Archivos Latinoamericanos de Nutrición; 46 (2): 159-62.

Jones SDM, Laug D, Tong AKW, Robertson WA. Commercial evaluation of video image analysis inthe grading of beef carcasses. Int Congr Meat Sci Technol 1992; 38: 915-18. 
Johnson LP, Willians SE, Neel SW, Reagan JO. Foodservice industry market profile study: nutritional and objective textural profile of foodservice ground beef. J Anim Sci 1994; 72: 1487-91.

Kasim-Karakas SE, Almario RU, Mueller WM, Peerson J. Changes in plasma lipoproteins during low-fat, high-carbohydrate diets: effects of energy intake. Am J Clin Nutr 2000; 71: 1439-47.

Kato H, Tillotson J, Nichamen MZ, Rhoads GG, Hamilton HB. Epidemiologic studies of coronary heart disease and stroke in Japanese men living in Japan, Hawaii and California: serum lipids and diet. Am J Epidemiol 1973; 97: 372-85.

Katz F. How nutritious meets how convenient? Food Technology 1999; 53: 4450.

Keenan JM \& Morris DH. Hypercholeterolemia: dietary advice for patients regarding meat. Postgratuate Medicine 1995; 98 (4): 113-26.

Kestin M, Rouse IL, Correll RA, Nestle PJ. Cardiovascular disease risk factors in free-living men: comparison of two prudent diets, one based on lactoovovegetarianism and the other allowing lean meat. Am J Clin Nutr 1989; 50: $280-87$.

Keys A, Anderson JT, Grande F. Prediction of serum-cholesterol responses of man to changes in fats in the diet. Lancet $1957 ; 2: 959-66$. 
Khalil AH. Quality characteristics of low-fat beef patties formulated with modified corn starch and water. Food Chemistry 2000; 68: 61-8.

Kirksey A, Wachs TD, Yunis F et al. Relation of maternal zinc nutriture to pregnancy outcome and infant development in na Egyptian village. Am J Clin Nutr 1994; 60: 782-922.

Kris-Etherton PM \& Yu S. Individual fatty acid effects on plasma lipids and lipoproteins: human studies. Am J Clin Nutr 1997; 65 (suppl): 1628S-44S.

Lamb MA, Robison OW, Tess MW. Genetic parameters for carcass traits in Hereford bulls. J Anim Sci 1990; 68:64.

Larysse M \& Garcia-Casal MN. Strategies for the prevention of iron deficiecy through foods in the household. Nutr Review 1997; 55: 233-9.

Lazzarini Neto S. A carne nelore para o consumidor. V Seminário Manah - O Nelore para carne. Fazenda Mundo Novo - Brotas/SP. 23 de junho de 1995.

Lira GM. Influência do colágeno sobre a textura de carnes. Higiene Alimentar $1997 ; 11(48): 12-18$.

Margen S. The University of California at Berkeley Welness letter. The Welness Encyclopedia of food and nutrition, New York: Rebus, 1992. 
Marmer WN, Maxwell RJ. Dry column method for the quantitative extraction and simultaneous class separation of lipids from muscle tissue. Lipids Champaign 1981; 16: 365-71.

Marshall DM. Breed differences and genetic parameters for body composition traits in beef cattle. J Am Sci 1994; 72: 2745.

Mills EW, Comerford JW, Harpster RH, House B, Henning WR. Meat composition and palatability of holstein and beef steers as influenced by forage type and protein source. J Am Sci 1992; 70:2446-51.

Ministério da saúde (MS)/OPAS. Guia alimentar para crianças menores de 2 anos: normas e manuais técnicos, série A, n. 107. Brasília; 2002.

Morgan JB, Savell JW, Hale DS, Miller RK, Griffin DB, Cross HR, Shackelford SD. National beef tenderness survey. J Anim Sci 1991; 69: 3274.

Morgan SA, Sinclair AJ, O'Dea K. Effect on serum lipids of addition of safflower oil or olive oil to very-low-fat diets rich in lean beef. J Am Diet Assoc 1993; 93: $644-48$

Morrison WR, Smith LM. Preparation of fatty acid methyl esters and dimethylacetals from lipids with boron fluoride-methanol. Journal of lipid research 1964; 5 (4): 600-8. 
National Institutes of Health. National Cholesterol Education Program. Washington (DC); 2001. (Publication, 01-3290).

National Research Council. Recomended dietary allowances. 10th ed. Washington, D.C.: National Academy Press, 1989.

Neves MF, Machado Filho CP, Carvalho DT, Castro L. Redes agroalimentares \& marketing da carne bovina em 2010. Preços agrícolas: mercados e negócios agropecuários $2001 ; 171: 7-18$.

Nicklas AT, Webber LS, Thompson B, Berenson GS. A multivariate model for assessing eating patters and their relationship with cardiovascular risk factors: the Bogalusa heart study. Am J Clin Nutr 1989; 49: 1320-7.

Nicklas AT, Farris RP, Myers L, Berenson GS. Impact of meat consumption on nutritional quality and cardiovascular risk factors in young adults: the Bogalusa Heart Study. J Am Diet Assoc 1995; 95: 887-92.

O'Brien B \& Reiser R. Human plasma lipid response to red meat, poutry, fish and eggs. Am J Clin Nutr 1980; 33: 2573-80.

O'Dea K, Traianedes K, Chrisholm K, Leycler H, Sinclair AJ. Cholesterollowering effect of a low-fat diet containing lean beef is reversed by the addition of beef fat. Am J Clin Nutr 1990; 52: 491-94. 
Ornellas LH. Técnica dietética: seleção e preparo de alimentos. $7^{a}$ ed. São Paulo: Atheneu, 2001.

Park SW, Addis PB. HPCL determination of C-7 oxidized cholesterol derivatives in foods. J Food Sci 1985; 50: 1437-41.

Pearson AM \& Dutson TR. Meat and health: advances in meat research. Elsevier Science Publishers Ltd.; 1990.

Pires JAA. Programas estaduais de apoio à produção de novilho precoce e confinamento. Encontro nacional dos confinadores e $5^{\circ}$ Encontro estadual do novilho precoce; 1997 ago 7-8; Uberlândia (BR). Campinas: Fundação Cargill, Campinas, 1998. p. 9 a 17.

Pohlman FW, Dikeman ME, Zayas JF, Unruh JA. Effects of ultrasound and convection to different end point temperatures on cooking characteristics, shear force and sensory properties, composition, and microscopic morphology of Beef Longissimus and Pectoralis Muscles. J Anim Sci 1997; 75: 386-401.

Poste LM, Butler G, Mackie D, Agar VE, Thompson BK, Cliplef RL, McKay RM. Correlations of sensory and instrumental meat tenderness values as affected by sampling techniques. Food Quality and Preference 1993; 4: 207-14.

Price JF \& Schweigert BS. Ciencia de la carne y dos productos cárnicos. $2^{\mathrm{a}}$ ed. Acribia. 1994. 
Puga DMU, Contreras CJC, Turnbull MR. Avaliação do amaciamento de carne bovina de dianteiro (Triceps branchii) pelos métodos de maturação, estimulação elétrica, injeção de ácidos e tenderização mecânica. Ciênc Tecnol Aliment 1999; $19(1): 88-96$.

Reddy MB, Hurrell RF, Juillerat MA, Cook JD. The influence of different protein sources on phytate inhibition of nonheme-iron absorption in humans. Am J Clin Nutr 1996; 63: 203-07.

Robinson DS. Bioquímica y valor nutritivo de los alimentos. España: ACRIBIA; 1991.

Rodbotten R, Nilsen BN, Hildrum KI. Prediction of beef quality attributes from early post mortem near infrared reflectance spectra. Food Chemistry 2000; 69: 427-36.

Roeber DL, Cannell RC, Belk KE, Tatum JD, Smith GC. Effects of a unique application of electrical stimulation on tenderness, color, and quality attributes of the beef longissimus muscle. J Anim Sci 2000; 78: 1504-9.

Saba A \& Di Natale R. A study on the mediating role of intention in the impact of habit and attitude on meat consumption. Food Quality and Preference 1999; 10: $69-77$. 
Sacks FM, Donner A, Castelli WP, Gronemeyer J, Pletka P, Margolius H, Landsberg L, Kass E. Effect of ingestion of meat on plasma cholesterol of vegetarians. JAMA 1981; 246: 640-44.

Sainz RD. Qualidade das carcaças e da carne bovina. ANAIS do $2^{\circ}$ congresso Brasil das raças zebuínas. 27 a 30 de outubro de 1996. Tema Central: "Reprodução genética aplicada aos zebuínos". p.28.

Saleh NT \& Ahmed ZS. Impact of natural sources rich in provitamin A on cooking characteristics, color, texture and sensory attributes of beef patties. Meat Sci 1998; 50 (3): 285-93.

Sant'Ana HMP, Penteado MVC, Stringheta PC. Tiamina, riboflavina e niacina em carnes. Uma revisão. Hig Alim 1998; 12 (8): 15-26.

Santiago RAC, Moreira-Araújo RSR, Pinto e Silva MEM, Arêas JAG. The potential of extruded chickpea, corn and bovine lung for malnutition programs. Food Science \& Emerging Technologies 2001; 2: 203-9.

SAS INSTITUTE. SAS/STAT user's guide, version 6. Cary, NC; 1990.

Scott LW,Dunn JK, Pownall HJ et al. Effects of beef and chicken consumption on plasma lipid level in hypercholesterolemic men. Arch Intern Med 1994; 154 (11): 1261-7. 
SENAI - MG (CETAL/FAM). Análise sensorial. Uberlândia; 1994. [Apostila do curso].

Shackelford SD, Koohmaraie M, Cundiff LV, Gregory KE, Rohrer GA and Savell JW. Heritabilities and phenotypic and genetic correlations for bovine postrigor calpastatin activity, intramuscular fat content, Warner-Bratzler shear force, retail product yield and growth rate. J Anim Sci 1994; 72:857.

Shackelford SD, Wheeler TL, Koohmaraie M. Repeatibility of tenderness measurements in beef round muscles. J Anim Sci 1998; 75: 2411-16.

Shaw NS, Chin CJ, Pan WH. A vegetarian diet rich in soybean products compromises iron status in young students. J Nutr 1995; 125: 212-19.

Silva LF \& Fabrini CF. Complexo avícola e questões sobre hábito alimentar. Cadernos de debate 1998; 6: 1-25.

Silva LSM. Prevalência de anemia e seus determinantes entre crianças de 0 a 36 meses que freqüentam escolas municipais infantis em Porto Alegre. Porto Alegre; 2000. [Tese de Doutorado - Universidade Federal do Rio Grande do Sul].

Sindicato do comércio varejistas de carnes frescas do estado de São Paulo (SCVCF): 60 anos de história e inovações. Desempenho das carnes entre 1986 e 1995, 1999. p.7. 
Sindicato do comércio varejista de carnes frescas do estado de São Paulo (SCVCF) b: 60 anos de história e inovações. Perfil do consumidor de carnes, 1999 c. p. $11-15$.

Slattery ML, Jacobs DR, Hilner JE, Caan BJ, Van Horn L, Bragg C, Manolio TA, Kushi LH, Liu K. Meat consumption and its association with other diet and health factors in young adults: the CARDIA Study. Am J Clin Nutr 1991; 54: 930-35.

Smit E, Javier Nieto F, Crespo CJ, Mitchell P. Estimates of animal and plant protein intake in US adults: Results from the Third National Health and Nutrition Examination Survey, 1988-1991. J Am Diet Assoc 1999; 99: 813-20.

Snowdon DA, Phillips RL, Fraser GE. Meat consumption and fatal ischemic heart disease. Prev Med 1984; 13: 490-500.

Snyder MP, Obarzanek E, Montgomery DH, Feldman H, Nicklas T, Raizman D et al. J Am Diet Assoc 1994; 94: 1135-39.

Spanier AM, Flores M, McMillin KW, Bidner TD. The effect of post-mortem aging on meat flavor quality in Brangus beef. Correlation of treatments, sensory, instrumental and chemical descriptors. Food Chemistry 1997; 59 (4): 531-8.

Stone H e Sidel JL. Sensory evaluation practices. Academic Press, 1985. 
Stradiotti Jr. D. Manejo para produzir carne com qualidade desejada pelos diferentes mercados. ANUALPEC 2002. P. 41-42.

Tatum J, Belk KE, George MH, Smith GC. Identification of quality management practices to reduce the incidence of retail beef tenderness problems: development and extration of a prototype quality system to procedure tender beef. J Anim Sci 1999; 77: 2112-18.

Taylor RG \& Koohmarai M. Effects of postmortem storage on the ultrastructure of the endomysium and myofibrils in normal and callipyge longissimus. J Anim Sci 1998; 76: 2811-17.

Terra NN. Apontamentos sobre tecnologia de carnes. São Leopoldo: Unisinos; 1998. Produção de carnes; p. 13-20.

Triola MF. Introdução à estatística. Rio de Janeiro: LTL ; 1999.

Tseng M, Chakraborty H, Robinson DT, Mendez M, Kohlmeier L. Adjustment of iron intake for dietary enhancers and inhibitors in population studies: bioavailable iron in rural and urban residing russian women and children. $\mathbf{J}$ Nutr $127 ; 1456-68.1997$.

Turpeinen O, Karvonen MJ, Pekkarinen M, Miettinen M, Elosuo R, Paavilainen E. Dietary prevention of coronary heart disease: The Finnish Mental Hospital Study. Int J Epidemiol 1979; 8: 99-118. 
Watt B \& Merril AL. Composition of foods: raw, processed, prepared. Washington, DC: Consumer and Food Economics Research Division/Agricultural Research Service; 1963. 198 p.(Agriculture Handbook, 8).

Watts GF, Ahmed W, Quiney J, Houlston R, Jackson P, lles C, Lewis B. Effective lipid lowering diets including lean meat. BMJ 1988; 296: 235-37.

Whipple G, Koohmaraie M, Dikeman ME, Crouse JD, Hunt MC, Klemm RD. Evaluation of attributes that afect longissimus muscle in Bos taurus and Bos indicus cattle. J Anim Sci 1990; 68: 2716-28.

Willet WC. Nutritional epidemiology. New York: Oxford University Press; 1998.

Wilkes JG, Conte ED, Kim Y, Holcomb M, Sutherland JB, Miller DW. Sample preparation for the analysis of flavors and off-flavors in foods. $J$ Chromatography A 2000; 880: 3-33.

Woodward BW, Pollak EJ, Quaas RL. Parameter estimation for carcass traits including growth information of Simmental beef cattle using restricted maximum likelihood with a multiple-trait model. J Anim Sci 1992; 70: 1098.

World Health Organization (WHO). Preventing and controlling iron deficiency anaemia through primary health care. Geneva; 1989. 
Van Vleck LD, Hakim AF, Cundiff LV, Koch RM, Crouse JD, Boldman KG. Estimated breeding values for meat characteristics os crossbred cattle. J Anim Sci $1992 ; 70: 363$.

Yip R. Iron deficiency: contemporary scientific issues and international programmatic approaches. J Nutr 1994; 124: 1479S-90S.

Yu S, Derr J, Etherton td, Kris-Etherton PM. Plasma cholesterol-predictive equations demonstrate that stearic acid is neutral and monounsaturated fatty acids are hypocholesterolemic. Am J Clin Nutr 1995; 61: 1129-39.

Uzcátegui SB, Leindez NH, Moreno LA, Colina G, Timaure NJ. Contenido de humedad, lipídos totales y ácidos grasos del músculo longissimus crudo de bovinos em Venezuela. Arch Latinoam Nutr 1999; 49 (2): 171-80. 


\section{ANEXO 1}

\section{QUESTIONÁRIO DE RECRUTAMENTO DE DEGUSTADORES}

Nome:

Idade:

Endereço:

Telefone residencial: Celular:

Horário e dias da semana que estuda/trabalha:

1. Quais os horários que você não poderá participar das sessões de degustação?

Manhã Tarde Noite

E os dias?

2. Cite alimentos e ingredientes que você desgosta muito?

3. Você é vegetariano?

4. Cite 3 alimentos ácidos

5. Cite 3 alimentos salgados

6. Cite 3 alimentos amargos

7. Cite 3 alimentos doces

8. Você é fumante?

9. Especifique os alimentos que você não pode comer ou beber por razões de saúde. Explique sua resposta, por favor

10. Você se encontra em dieta por razões de saúde ou estética? Em caso positivo, explique, por favor, qual dieta

11. Indique se você possui:

( ) Diabetes

( ) Hipertensão

( ) Hipoglicemia

( ) Doença bucal

( ) Dentadura, aparelho, prótese

( ) Colesterol alto

12. Você gostaria de ser degustador de nossa pesquisa para avaliar o produto: contra filé do animal Novilho Precoce? 


\section{ANEXO 2}

\section{Manual de instruções introdutórias de}

\section{Análise sensorial}

\section{Oquê é Avaliaçăo Sensorial?}

É uma ciência que define objetivamente e mede a qualidade sensorial dos alimentos através das caracteísticas sensoriais:

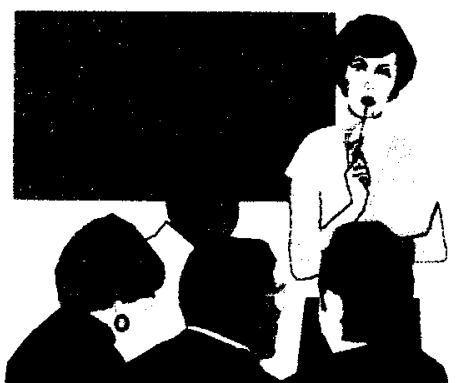

ASPECTO: Nada mais é que a visualização da cor, tamanho do produto dentro de suas características normais. Por exemplo: o consumidor compra um litro de leite e espera que este produto tenha seu visual dentro dos padrôes normais específicos.

GOSTO/SABOR: é o gosto que o alimento provocará ao ser degustado. Por exemplo: amargo, ácido, salgado, doce ou combinação de dois ou mais destes, detectado através da língua. Percebemos ao mesmo tempo, odor (percepção de substâncias voláteis, por meio do nariz ) e o aroma (percepção de substâncias aromáticas de um alimento, após ser colocado na boca). O odor e o aroma seriam a percepção do cheiro. Por exemplo: o aroma delicioso de uma comida, vindo da cozinha. 
MACIEZ: é a percepção da força necessária para, ao morder, obter esmagamento, deformação da amostra.

SUCULÊNCIA: é a percepção de líquidos da carne ao ser mordida.

\section{Qual o objetivo da Avaliação Sensorial?}

Tem como objetivo contribuir para aumentar a competitividade no mercado, desenvolver e garantir a qualidade de produtos, através de avaliações de preferência e aceitação.

Curiosidade: $50 \%$ das queixas dos consumidores referem-se à condição organoléptica, ou seja, condições anormais de aroma, textura, sabor, aspecto, etc.

\section{Qual o papel da Avaliação Sensorial no controle de qualidade?}

O controle de qualidade nada mais é que a ação de garantir a qualidade de cada prouto que vai para o mercado consumidor. São as principais características de qualidade do produto. Dividem-se em:

- Características não visíveis

- Segurança: fator microbiológico, embalagens perfeitas, etc.

- Nutrição: fator relacionado com a legislação do produto

- Características visíveis

- características sensoriais: estes atributos são controlados através das Análises Sensoriais. Para que esxista um controle de qualidade das 
características Sensoriais é necessário selecionar e treinar um grupo de degustadores que controlarão a liberação do produto para o mercado consumidor.

- Por isso estamos realizando a seleção para degustadores

\section{Boas práticas de Análes sensoriais}

As seguintes recomendações têm o objetivo de diminuir a confusão e fazer com que se obtenham os benfícios máximos possíveis em cada sessão de degustação:

- Deve-se evitar o uso de perfumes quando se vai participar de um teste sensorial.

- Deve-se lavar as mãos antes de um teste, usando sabonete sem perfume.

- O degustador que estiver resfriado ou com outras infecções repiratórias não deve participar dos teste sensoriais e deve avisar com antecedência o laboratório.

- Os degustadores não devem fumar ou beber café pelo menos 30 minutos antes do teste.

- Ler todas as instruções e, se não entender, perguntar ao instrutor.

- Não conversar para não perder a concentração.

- Pontualidade é imprescindível.

- Sempre enxaguar a boca para tirar os sabores residuais entre as degustações das amostras. 
ANEXO 3

ANÁLISE SENSORIAL - FICHA DE AVALIAÇÃO

Nome:

Data:

Idade: menos de 21 anos:

de 21 a 30 anos:

de 31 a 40 anos:

de 41 a 50 anos:

Prove as amostras codificadas da esquerda para a direita e circule abaixo o código da amostra mais:

$\begin{array}{lll}\text { Saborosa: } & 572 & 647 \\ \text { Macia: } & 572 & 647 \\ & & \\ \text { Suculenta: } & 572 & 647\end{array}$

Comentários: 


\begin{abstract}
ANEXO 4
CONSENTIMENTO - Resolução no 196, de 10 de outubro de 1996, segundo o Conselho nacional de Saúde
\end{abstract}

$\mathrm{Eu}$, aceito livremente participar do estudo "Qualidade nutricional e características sensoriais da carne de novilho precoce", sob responsabilidade dos pesquisadores Maria Elisabeth Machado Pinto e Silva, da Faculdade de Saúde Pública (FSP) da Universidade de São Paulo (USP) e Estefânia Maria Soares Pereira, doutoranda do curso de Saúde Pública.

Propósito do estudo: avaliar a qualidade nutricional e características sensoriais da carne de novilho precoce

Participacão: os responsáveis pelo estudo prestarão esclarecimentos sobre todos os procedimentos a serem realizados, após recrutamento voluntário. Concordando, deverei responder a um questionário específico sobre degustação e degustar as amostras de carnes.

Riscos: este estudo não trará qualquer risco para minha integridade física ou moral.

Benefícios: as informações obtidas neste estudo serão úteis cientificamente para se possibilitar intervenções nutricionais oportunas. A partir dele, poderá ser desenvolvida uma linha de pesquisa em benefício da população em geral.

Privacidade: as informações científicas obtidas neste estudo poderão ser divulgadas em publicações, congressos, porém, sem a identificação dos participantes. Minha participação é, portanto, voluntária, podendo desistir a qualquer momento do estudo, sem qualquer conseqüência para mim. 